\title{
A Unique Kex2-like Endoprotease from Drosophila melanogaster Is Expressed in the Central Nervous System during Early Embryogenesis
}

\author{
Joel S. Hayflick, William J. Wolfgang, Michael A. Forte, and Gary Thomas \\ Vollum Institute and Department of Cell Biology and Anatomy, Oregon Health Sciences University, Portland, Oregon \\ 97201-3098
}

\begin{abstract}
Complementary DNA sequences were cloned from a Drosophila library encoding a 1101 amino acid polypeptide that we have named dKLIP-1. The deduced protein is structurally similar to the yeast KEX2 prohormone endoprotease including the conserved Asp, His, and Ser catalytic triad residues characteristic of the subtilisin family. When coexpressed in vivo with pro- $\beta$-NGF, dKLIP-1 greatly enhanced the endoproteolytic conversion of the precursor to mature $\beta$-NGF by cleavage at a -Lys-Arg- doublet. In adults, dKLIP-1 transcripts were detected in cortical regions of the CNS and fat body. Most striking, however, was the high level of maternal transcripts deposited into developing oocytes. The temporal and spatial expression of dKLIP. 1 mRNAs during embryonic development indicates a potential role for this novel Kex2plike endoprotease in early embryogenesis and neurogenesis.
\end{abstract}

Endoproteolysis of precursor proteins is a common step required for the synthesis of biologically active proteins and peptides in all eukaryotes examined, including yeast (Fuller et al., 1988), invertebrate (Scheller et al., 1983), and mammalian cells (Douglass et al., 1984). Typically, the cleavage occurs at the carboxyl side of pairs of basic amino acid sequences (especially -LysArg- and -Arg-Arg-). Excision of bioactive peptides and proteins by cleavage at doublets of basic amino acids was first proposed from studies of proinsulin (Steiner et al., 1967; Chance et al., 1968) and the ACTH/ $\beta$-endorphin precursor proopiomelanocortin (POMC) (Chretien and Li, 1967). Subsequent studies have revealed a broad spectrum of precursor proteins that require endoproteolysis at pairs of basic amino acids to yield mature peptides, including serum factors (Bentley et al., 1986),

\footnotetext{
Received Sept. 3, 1991; accepted Oct. 10, 1991.

We thank P. Salvaterra for the Drosophila head cDNA library and S. Ojeda for the $\beta$-NGF antisera. We thank R. Leduc for his efforts in the early stages of this project and helpful discussions. We are indebted to $\mathrm{S}$. Smolik-Utlaut for analysis of the chromosomal localization and helpful discussions and to P. Bresnahan for help and instruction in the coexpression studies. We thank $L$. Thomas, P. Bresnahan, S. Molloy, L. Band, and M. Chinkers for critically reading the manuscript. We also thank J. Shiigi, V. Robertson, and P. Keating for illustrations. This work was supportcd by the Oregon Medical Research Foundation (MRF-797); American Diabetes Association, Oregon Chapter (G.T.); and NIH Grants DK 37274 (G.T.) and NS 27684 (M.A.F.). J.S.H. is the recipient of an N. L. Tartar Fund Research Award.

Correspondence should be addressed to Dr. Gary Thomas, Vollum Institute, The Oregon Health Sciences University, 3181 SW Sam Jackson Park Road, Portland, $O R$ 97201-3098.

Copyright @ 1992 Society for Neuroscience 0270-6474/92/120705-13\$05.00/0
}

viral envelope proteins (McCune et al., 1988), growth factors (Mason et al., 1985), and receptors (Yoshimasa et al., 1988).

A number of activities capable of cleaving at paired basic residues in vitro have been proposed as candidates for authentic mammalian precursor processing endoproteases (reviewed in Sossin et al., 1989); however, none have been shown to be a bona fide precursor cleaving endoprotease in vivo. In contrast, genetic and biochemical studies unequivocally identified the gene in Saccharomyces cerevisiae required for excision of the $\alpha$-factor mating hormone from its precursor (Leibowitz and Wickner, 1976; Julius et al., 1984). This locus, the KEX2 gene, encodes a subtilisin-like, membrane-bound, calcium-dependent, serine endoprotease (Kex $2 p)$ specific for cleaving on the carboxyl side of pairs of basic residues (-Lys-Arg- and -ArgArg-) (Fuller et al., 1989a; Mizuno et al., 1989).

Several lines of evidence suggest that precursor processing endoproteases in higher eukaryotes are functionally and, hence, structurally similar to Kex $2 \mathrm{p}$. The mammalian precursor proalbumin, for example, is efficiently converted in vitro to albumin by $\operatorname{Kex} 2 \mathrm{p}$, with cleavage at a paired basic amino acid scquence (-Arg-Arg-) (Bathurst et al., 1987). Furthermore, coexpression of the $K E X 2$ gene with mouse POMC in BSC-40 cells (a line incapable of processing this peptide precursor) resulted in efficient proteolysis, on the carboxyl side of basic amino acid pairs, producing authentic pituitary peptides (Thomas et al., 1988a).

Recently, three DNA sequences, fur, PC2, and PC3 (also called PC1) have been reported, which share significant sequence identity with the $K E X 2$ gene sequence (Fig. 1) (Fuller et al., 1989b; Seidah et al., 1990, 1991; Smeekens and Steiner, 1990; van den Ouweland et al., 1990; Wise et al., 1990; Smeekens et al., 1991). RNA hybridization studies demonstrate that the fur gene is ubiquitously expressed in a variety of tissues and all cell lines examined (Schalken et al., 1987; Bresnahan et al., 1990; Hatsuzawa et al., 1990). In contrast, expression of PC2 and PC3 is restricted to neuroendocrine tissues. Gene transfer studies demonstrated that the fur gene product, furin, as well as PC2 and PC3, are Kex $2 p$-like endoproteases capable of efficiently processing precursor proteins at pairs of basic amino acids (Bresnahan et al., 1990; van de Ven et al., 1990; Wise et al., 1990; Benjannet et al., 1991; Thomas et al., 1991). Like Kex2p, furin is a Golgi membrane-localized endoprotease that can efficiently process pro- $\beta$-NGF when coexpressed in mammalian cells (Bresnahan et al., 1990). Comparable results were reported on the enhanced processing of pro-von Willebrand factor by furin (van de Ven et al., 1990; Wise et al., 1990). In contrast, the neuroendocrine-specific endoproteases PC2 and PC3 cleave 


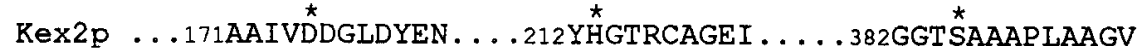

$$
\begin{aligned}
& \text { hfurin . . 149VSILDDGIEKNH . . . 193RHGTRCAGEV . . . . 365TGTSASAPLAAGI } \\
& \text { hPC2 . . 138IGIMDDGIDYLH . . .207SHGTRCAGEV . . . 381SGTSAAAPEAAGV } \\
& \text { Consensus --I-DDG---- -HGTRCAGE- -GTSA-AP-AAG- }
\end{aligned}
$$

Figure 1. Alignment of the amino acid sequences surrounding the catalytic triad residues in Kex2p, human furin (hfurin), and human PC2 ( $h P C 2$ ). The coding sequences surrounding the His and Ser residues showed greatest sequence identity and therefore were used for the design of PCR primer pools. The amplified $\sim 542$ bp product predicted from PCR experiments was determined by adding the lengths of the primers (24 and 32 bases) to the sequence in Kex2p that separated their 3 ' ends (486 bases). Computer-based alignment of polypeptide sequences for Kex2p (Mizuno, 1988), hfurin (van de Ouweland et al., 1990), and hPC2 (Smeekens and Steiner, 1990) was done using the BEsTFIT program (Devereux et al., 1984). Nonidentical residues are shown by dashes in the consensus (bottom) line. The asterisks denotc asparigine, histidine, and serine residues of the catalytic triad.

mouse POMC correctly at doublets of basic amino acids into sets of pituitary peptides (Benjannet et al., 1991; Thomas et al., 1991).

The identification of multiple Kex 2 p-like endoproteases expressed in a wide variety of tissues and cell lines suggests that each homolog catalyzes the maturation of several bioactive peptides and proteins. In yeast, genetic tools have been key to understanding the role of Kex $2 \mathrm{p}$. Unlike yeast, however, mammalian systems are generally intractable to classical genetic analyses. In contrast, Drosophila provides an excellent system to examine the role of this newly identified group of metazoan precursor endoproteases. With Drosophila, the tools of classical and molecular genetics can be applied systematically in an organism in which each of the developmental stages is well described and easily accessible (Rubin, 1988). To this end, we report here the cloning, tissue and developmental expression, and endoproteolytic activity of a Drosophila Kex 2 p-like endoprotease (dKLIP-1).

\section{Materials and Methods}

Fly stocks and reagents. Oregon $\mathrm{R}$ stocks were maintained at $25^{\circ} \mathrm{C}$ on $12 \mathrm{hr}$ light/12 hr dark schedules on a standard diet (Roberts, 1986). Restriction enzymes T7 RNA polymerase, SP6 RNA polymerase, and Taq DNA polymerase were purchased from Bethesda Research Labs, Inc. (BRL). Oligonucleotides were purchased from Oligos Etc. Inc. The adult fly head gt11 library was a gift from P. Salvaterra (City of Hope, Duarte, CA). Oligo-dT cellulose was purchased from Boehringer Mannheim Biochemicals, Inc.

Cell culture. BSC-40 cells, an African green monkey kidney epithelial cell line, and HeLa cells, a human cervical epithelial cell line, were cultured in minimum essential medium (MEM) (GIBCO Laboratories) containing $10 \%$ heat-inactivated fetal bovine serum (HyClone Laboratories).

Polymerase chain reaction and library screening. Two micrograms of $\lambda$-DNA from the library used below containing oligo-dT-primed adult head-specific cDNAs were amplified with 100 pM each of two oligonucleotide pools: pool 1, 5'-CA(C/T)GG(C/A/T)AC(C/G)CG(A/C/ G)TG(T/C)GC(C/G)GG(A/T/C)GA(G/A); pool 2, 5'-CC(G/A)GC(G/ A)GCCA(G/A)GGG(G/A)GCGG(A/C)(G/A)GC(G/A/T/C)GAGG$T(G / T) C C$. Twenty-five microliter $P C R$ reactions were performed using Taq polymerase with temperature and time parameters of $95^{\circ} \mathrm{C}, 1 \mathrm{~min}$, $55^{\circ} \mathrm{C}, 1 \mathrm{~min}, 74^{\circ} \mathrm{C}, 1 \mathrm{~min}$ for 30 cycles. The product was agarose gel purified and subcloned into pGEM7Zf + (Promega Corp.). One hundred nanograms of PCR product were radio labeled by the random primer method (Feinberg and Vogelstein, 1983) and used to screen $5 \times 10^{5}$ plaques of the $\lambda \mathrm{gtl} 1 \mathrm{fly}$ head library. Hybridization was performed in $50 \%$ formamide, $1 \%$ SDS, $1 \mathrm{M} \mathrm{NaCl}, 10 \%$ dextran $\mathrm{SO}_{4}$, and $100 \mu \mathrm{g} / \mathrm{ml}$ sheared, denatured salmon sperm DNA at $37^{\circ} \mathrm{C}$ for $18 \mathrm{hr}$. Filters were washed briefly in $2 \times$ SSC (saline-sodium citrate) at room temperature and then in $0.1 \% \mathrm{SDS}, 0.1 \times \mathrm{SSC}$ at $65^{\circ} \mathrm{C}$ for $60 \mathrm{~min}$. Positively hybridizing clones were purified and two phage isolates (1L and 3) were chosen for further study. The composite dKLIP-1 cDNA (see Fig. $3 A$ caption) was ligated into the EcoR 1 site of $\operatorname{pEEM} 7 \mathrm{Z} f+$, and the resulting plasmid (pGEM7Zf $+:$ KLIP-1) was used for later studies.
$D N A$ sequencing. Fragments of $\lambda$-phages 3 and $1 \mathrm{~L}$ were subcloned into M13mp18 or mp19 vectors (Yanisch-Perron et al., 1985) and sequenced using the dideoxynucleotide chain terminator method (Tabor and Richardson, 1987) and Sequenase v2 (U.S. Biochemical). Reactions were run on 5\% denaturing polyacrylamide wedge gels (Chen and Seeburg, 1985). Sequences of overlapping restriction fragments were determined from both DNA strands.

Computer analyses. DNA sequences were compiled and analyzed using the Genetics Computer Group Sequence Analysis Software Package, version 6.2, 1990 (Devereux et al., 1984) or the Intelligenetics, Inc. programs. The deduced protein sequence for dKLIP-1 was compared to the Kex2p homologs using the BESTFIT and GENALIGN programs. Hydrophobicity analysis was performed using the PEPPLOT program.

$R N A$ isolation and Northern blot analyses. Fly heads were separated from bodies and stored at $-70^{\circ} \mathrm{C}$ until use. Staged embryos were collected on apple juice agar plates and maintained at $25^{\circ} \mathrm{C}$ until harvest. One gram of whole flies or parts was crushed in liquid $\mathrm{N}_{2}$. Total RNA was isolated as described (Cathala et al., 1983). Ten micrograms of each polyA'-selected RNA sample were fractionated by electrophoresis in $1 \%$ agarose (FMC), $6 \%$ formaldehyde, 0.02 м HEPES, 0.001 м EDTA pH 7.8 gels and transferred to a nylon membrane (Hybond-N, Amersham). Hybridizations were carried out in $50 \%$ formamide, $5 \times \mathrm{SSC}$, $0.025 \mathrm{M} \mathrm{NaPO}_{4}, 5 \times$ Denhardt's solution, $0.005 \mathrm{M}$ EDTA, $0.1 \%$ sodium pyrophosphate, $1 \%$ SDS, and $100 \mu \mathrm{g} / \mathrm{ml}$ sheared, denatured salmon sperm DNA at $37^{\circ} \mathrm{C}$ for $18 \mathrm{hr}$. Blots were washed in $2 \times \mathrm{SSC}$ at room temperature and $0.1 \times \mathrm{SSC}, 0.1 \%$ SDS at $65^{\circ} \mathrm{C}$ for $60 \mathrm{~min}$. Filters were then exposed to X-OMAT AR film (Kodak).

In vitro expression. RNA was synthesized in vitro essentially as described (Kreig and Melton, 1987). Briefly, $10 \mu \mathrm{g}$ of pGEM7Zf + :dKLIP-1 were linearized with XhoI endonuclcase. Fifty microliter RNA transcription reactions contained $1 \mu \mathrm{g}$ of linearized plasmid DNA in $1 \times$ SP6 buffer; $0.01 \mathrm{~m}$ dithiothreitol DTT; $50 \mu \mathrm{g} / \mathrm{ml}$ bovine serum albumin; $1 \mathrm{U}$ placental RNase inhibitor (Promega); $250 \mu \mathrm{M}$ each ATP, CTP, and UTP; $50 \mu \mathrm{M}$ GTP; $250 \mu \mathrm{M}$ GpppG; and $50 \mathrm{U}$ of SP6 RNA polymerase (BRL). Incubations were performed at $37^{\circ} \mathrm{C}$ for $5 \mathrm{hr}$. RNA was extracted twice with phenol: chloroform, ethanol precipitated, and resuspended in $50 \mu \mathrm{l} \mathrm{H}_{2} \mathrm{O}$. Fifty microliter in vitro translation reactions containing in vitro transcribed RNA, rabbit reticulocyte lysate (Promega) and ${ }^{3} \mathrm{H}-$ leucine were set up as described by the manufacturer. After $30 \mathrm{~min}$ at $30^{\circ} \mathrm{C}, 10 \%$ of the translation reaction was run on a $7 \%$ SDS-PAGE (Laemmli, 1970), which was then processed for fluorography (Amplify, Amersham). The dried gel was exposed to X-OMAT film for $16 \mathrm{hr}$ at $-70^{\circ} \mathrm{C}$. For translation/translocation studies, canine pancreatic microsomes (Promega) werc added to the reticulocyte reactions. Protease-digested reactions were adjusted to $0.01 \mathrm{M} \mathrm{CaCl}_{2}$ and 0.1 $\mathrm{mg} / \mathrm{ml}$ proteinase $\mathrm{K}$, and detergent-disrupted reactions were brought to $0.1 \%$ Triton X-100. Following a $45 \mathrm{~min}$ incubation on ice, the digestions were terminated by adjusting to $2 \mathrm{~mm}$ phenylmethylsulfonyl fluoride and analyzed by SDS-PAGE as described above.

Vaccinia virus. Vaccinia virus (VV) strain WR was used and infections were performed as described (Thomas et al., 1988b). Recombinant virus carrying the dKLIP-1 cDNA was constructed as follows. The 3.8 kilobase $(\mathrm{kb})$ dKLIP-1 cDNA was ligated directionally into pZVneo. The plasmid pZVneo contains the vaccinia thymidine kinase gene interrupted by a VV expression/selection cassette putting the expression of dKLIP-1 under the control of the constitutive $p 7.5 \mathrm{VV}$ promoter. The Tn5 aminoglycoside transferase gene driven by the VV p11 promoter acts as a selectable marker by conferring ncomycin resistance. The resulting plasmid (pZVneo:dKLIP-1) was used to introduce the cDNA 
and plasmid flanking sequences into vaccinia virus by homologous recombination (Hruby et al., 1986). Purified isolates of VV:dKLIP-I were used for the production of viral stocks.

Coexpression studies of dKLIP-1 with murine pro- $\beta$-NGF were performed essentially as described (Bresnahan et al., 1990). Briefly, parallel wells of BSC-40 cells were infected with VV:mNGF $(\mathrm{m} .0 . i .=2)$ and either VV:WT or VV:dKLIP-1 (m.o.i. $=5$; total m.o.i. $=7$ ). At $19 \mathrm{hr}$ postinfection, the cells were starved for methionine for $30 \mathrm{~min}$ and then pulsed with $100 \mu \mathrm{Ci}^{35} \mathrm{~S}-\mathrm{Met}$,Cys (Express Label, New England NuclearDu Pont). After $3 \mathrm{hr}$, the medium was harvested and secreted products were immunoprecipitated by overnight incubation with a rabbit antimouse $\beta$-NGF serum (gift of S. Ojeda), following which immune complexes were collected using Protein-A Sepharose beads (Zymed Labs). The beads were washed twice with $1 \% \mathrm{NP} 40 / 1 \mathrm{M} \mathrm{NaCl}$ and twice in RIPA buffer (Harlow and Lane, 1988). Immune complexes were analyzed by SDS-PAGE in 12.5\% gels (Laemmli, 1970). Fixed gels were then impregnated with fluor (Amplify, Amersham) and exposed to $\mathrm{x}$-ray film.

In situ hybridizations. Sense and antisense RNA probes were generated by using the SP6 or T7 promoters of pGEM7Zf + :dKLIP-1 using $\alpha-{ }^{35}$ S-thio-UITP. Probes were hybridized to $8 \mu \mathrm{m}$ tissue sections that had been mounted on microscope slides and fixed with $4 \%$ formaldehyde, then treated in $0.2 \mathrm{M} \mathrm{HCl}$ for $20 \mathrm{~min}, 2 \times \mathrm{SSC}$ for $30 \mathrm{~min}$ at $60^{\circ} \mathrm{C}$, proteinase $\mathrm{K}$ at $37^{\circ} \mathrm{C}$ for $15 \mathrm{~min}, 4 \%$ formaldehyde for $20 \mathrm{~min}$, and then acetylated and dried (Hafen and Levine, 1986). After overnight hybridization at $50^{\circ} \mathrm{C}$, the sections were rinsed briefly in $4 \times$ SSC and then incubated for $15 \mathrm{~min}$ at $60^{\circ} \mathrm{C}$ in $50 \%$ formamide, $0.3 \mathrm{M} \mathrm{NaCl}, 0.03$ $\mathrm{M}$ Tris, pH 7.5, $1 \mathrm{~mm}$ EDTA, and $10 \mathrm{~mm}$ DTT. The slides were then washed in 4 liters of $2 \times \mathrm{SSC}$ at $25^{\circ} \mathrm{C}$ for $30 \mathrm{~min}, 0.1 \times \mathrm{SSC}\left(55^{\circ} \mathrm{C}, 10\right.$ $\mathrm{min})$ and $0.1 \times \mathrm{SSC}\left(25^{\circ} \mathrm{C}, 10 \mathrm{~min}\right)$. After drying the slides were coated with photographic emulsion (Kodak NTB2).

Embryos were collected and prepared by previously described methods (Mitchison and Sedat, 1983). Sense and antisense transcripts were synthesized in the presence of digoxigenin-11-UTP (Boehringer Mannheim). Following RNase-free DNase treatment, the transcripts were subjected to limited hydrolysis in $0.1 \mathrm{M}$ carbonate buffer, $\mathrm{pH} 10.2$ (Angerer and Angerer, 1981), yielding fragments of 100-125 nucleotides as determined by gel electrophoresis. Whole-mount embryo hybridization and detection were done as previously described (Tautz and Pfeifle, 1989). Embryonic stages are as described by Campos-Ortega and Hartenstein (1985).

\section{Results}

\section{Cloning and characterization of the $d K L I P-1 \mathrm{cDNA}$}

A strategy for the identification of cDNAs encoding Kex2p-like endoproteases from Drosophila was developed by examining an alignment of the amino acid sequences of human furin (hfurin) (van de Ouweland, 1990), human PC2 (hPC2) (Smeekens and Steiner, 1990), and yeast Kex2p (Mizuno et al., 1988). Significant identity exists in the amino acid sequences that surround the residues forming the catalytic triad (Asp, His, and Ser), with the greatest scquence conservation around the histidine and serine residues (Fig. 1). Based on this conservation and on Drosophila codon bias data (Wada et al., 1990), two degenerate oligonucleotide primer pools were designed for use in PCR (Saiki et al., 1988). The first primer pool was a sense 24 mer that encoded eight amino acids beginning with the active-site histidine residue. The second primer pool was an antisense $32 \mathrm{mer}$ corresponding to the coding region for the 11 amino acids surrounding the active-site serine residue. A subset of these oligonucleotide primers was expected to anneal to Drosophila Kex2p-like cDNA sequences, producing an amplified product of $\sim 542$ base pairs (bp). Indeed, PCR experiments using template DNA prepared from a Drosophila adult head cDNA library resulted in the isolation of an $\sim 550$ bp product. DNA sequence analysis demonstrated the presence of an open reading frame (ORF) that shared significant homology to the predicted region of the Kex $2 \mathrm{p}$-like endoproteases.

Two independent phage clones were isolated from the adult head library using the labeled PCR product as a probe (Fig. $2 A$ ). Clones 3 and $1 \mathrm{~L}$ contained cDNA inserts of 3.5 and $2.8 \mathrm{~kb}$, respectively. Clone $1 \mathrm{~L}$ contained an ORF with a methionine residue at nucleotide (nt) 232 and extended to the $3^{\prime}$ end of the sequence. The nucleotide sequence surrounding this putative initiation codon (Fig. 2B, nt 225-235) was identical to the Drosophila consensus translation initiation site [ANN(C/A)A(A/ C)(A/C)ATGN; Cavener, 1987]. In addition, this methionine residue was preceded by several in frame termination codons. Clone 3 initiated at nucleotide 240 of clone $1 \mathrm{~L}$ and continued to a termination codon at position 3535 . The protein product predicted from the two overlapping cDNA sequences was 1101 amino acids in length. A composite cDNA (hereafter referred to as the dKLIP-1 cDNA) of 3.78 kilobase pairs containing the complete ORF for dKLIP-1 was created (Fig. $2 A$ ).

The dKLIP-1 cDNA contained several interesting features. Proximal to the putative initiator methionine was an opa element (Fig. 2B, nt 258-347), a $\mathrm{CAX}_{n}$ trinucleotide repetitive sequence found in several developmentally regulated mRNAs (Wharton et al., 1985; Grabowski et al., 1991). The 245 nucleotide $3^{\prime}$ untranslated region (UTR) contained several AUUUA repeats (Fig. $2 B$, nt 3570 and 3744), a motif that affects mRNA instability (Shaw and Kamen, 1986), and a canonical polyadenylation addition sequence (AAUAAA, nt 3755; Proudfoot and Brownlee, 1976) $19 \mathrm{bp}$ from a polyA sequence.

The location of the gene encoding dKLIP-1 was identified by in situ hybridization of a biotin-labeled dKLIP-1 cDNA probe to Drosophila salivary gland chromosomes. Hybridization was observed on the right arm of chromosome 3 at position 96D1-2 (data not shown).

\section{Characterization of the predicted $d K L I P-1$ polypeptide}

Hydrophobicity analyses of the Kex $2 \mathrm{p}$-like endoproteases indicated that each has an amino terminal hydrophobic sequence (signal sequence) (Fig. $3 B$ ). In the case of $\operatorname{Kex} 2 \mathrm{p}$, this sequence has been shown to target the protein into the secretory pathway, where it becomes glycosylated (Fuller et al., 1986, 1989b). A similar analysis of the predicted protein sequence of dKLIP-1 using a hydrophobicity algorithm (Kyte and Doolittle, 1982) showed that, unlike the other Kex2p-related proteins, dKLIP-1 lacks a signal sequence at its amino terminus. The hydrophobic domain nearest to the amino terminus is situated between residues 118 and 151 (Fig. $3 A$ ). This analysis also indicated the presence of a second hydrophobic region near the carboxyl terminus in dKLIP-1 (residues 1006-1036), similar to Kex 2 p and furin, that is a putative transmembrane domain.

The percentages of overall amino acid sequence conservation between dKLIP-1 and other members of this proteinase family are shown in Table 1 . The most conserved region of dKLIP-1 is the subtilisin-like catalytic domain (Fig. 3C), suggesting functional and structural homology with other members of this family. In addition to highly conserved catalytic domains, Kex $2 p$ and its mammalian homologs have similar sizes, ranging from 638 residues for hPC. 2 to 814 residues for Kex 2 p (Fig. $3 B$ ). In contrast, the predicted length of dKLIP-1, 1101 residues, is significantly longer than any reported Kex 2 p-related sequence. Alignment of the catalytic domains of each of the Kex $2 p$-like homologs indicates that the longer size of dKLIP-1 is due to an extended amino-terminus. The alignment also results in a shared positioning of two sets of paired basic residues in dKLIP-1 (-Lys ${ }^{276}-\mathrm{Arg}^{277}$ - and $-\mathrm{Lys}^{308}-\mathrm{Arg}^{309}-$ ) with a small cluster of paired basic amino acids in the other homologs that could be 


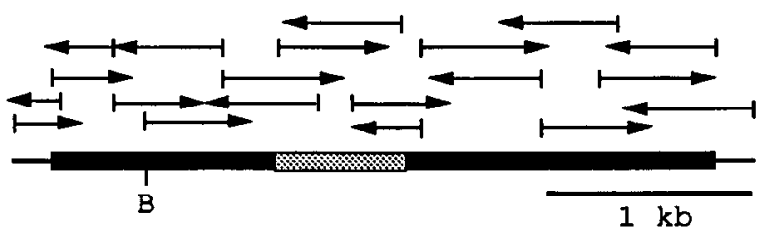

GACAACAACAAATTTAAATTGAGATTTTCCATATTATCAAAAGTTACAGGCGCCTATTTTGCAGTTATCAGTCTGAAGTCGGTGTGAAGTGCTATCCTGGACTTTTCGTTTTAGTCACCC 120 CTTGGCCTCATCTAACATCCACTTAATTGAAATAGACATTIGCATCTCAGCCTCACAACCAATATCCCGAGCAACGTGCACAAAAACTATTGGAAAAATCCTAACCCACAATGAAAAAC 240 GACGTCGTGCGATGGAGCAGGCAGCCAACTAGCAACACCACTAACAGCAGCAGCAGCAGTAGAAGCGATAGCAACAGCACTCATAAGCACAGAAGCAAAGCAACAAATTAAATGCTCGA 360 AspValValargTrpSerArgGInProThrSerAsnThrThrAsnSerSerSerSerSerArgSerAspSerAsnSerThrHisLysHisArgSerLysSerAsnLysLeuAsnAlaArg 43

CAATTAGGGTCAAATGCTGCCAGAATTGTCAGCAAAGATCCTCTGTGGCAACAACACTAGAAGATGAACAACAAACAATCATTGAATGTGATATAGGAAATTTCAATTTCGATTGCAAT 48O

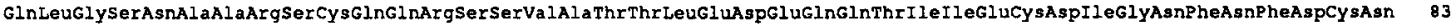

TTATTCAAAACTAGTTTTTTPAACGCAACACAAACAGAAACGTAGTGGCAAGAGCAGCAGCAAAAGTAAGAGCAACAGAAGTAGACCCCTAGCGAAAACGAANGCGGTGTTTCTATTAGCT 600 LeuPheLysThrSerPheLeuThrGInHisiysGlnLysArgSerGlyLysSerSerSerLysSerLysSerAsnArgSerArgProLeuAlaLysThrLys AlaValPheLeuLeuAla 123 CTGCAATTTAGTGCCGTAGTTTTTTTATGTAATATTAATGTCGGTTTCGTGGCCGGAAGTGTGGCAACTGCGGCATCATCGGCAEGCGGCTCATCGCCGGCAGCTCCATCATCTGCGCCC 720

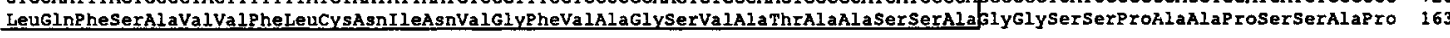
TCATCCCCGCCCACAGTTGCIGTACCACCGCCGCCGCCACCTTCGTCGGCACTCAAAGTGGATCCAAATGGTCAGTCACCAGTGCTGCCGCCCTACGTTCTCGATTATGAGACGGGGGGC 840

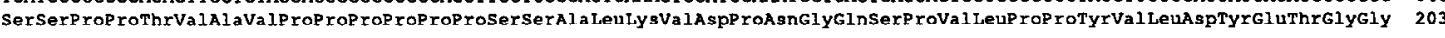
AAGGCCAAGCTAACGCCAAACAATGGCAAGTTCGGCCAATCGGGCAGTTCCGGGAGCAATAACAACCACATCGTCGGACACTATACCCACACCTGGGCGGTCACATACCAAACGGCGT 960

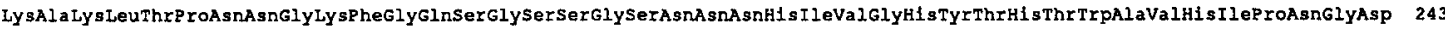

AATGGCATGGCCGATGCGGTTCCAAGGATCACGGATTCGTCAATTTGGGCAAGATCTTCGATGATCACTACCACTTCGCACATCACAAGGTCTCGAAGCGTTGCTCTCCCCCGCCACG 1080

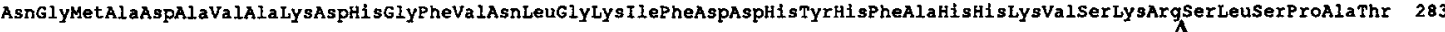
CATCACCAAACTCGCCTGGATGACGACGATCGCGTCCACTGGGCGAMGCAGCAGCGGGCCAAGTCGCGATCCAAACGGGACTTTATCCGCATGCGACCCTCACGGACCTCCTCGCGAGCC 1200 HisHIsGInThrArgI CUASPAspAspAspArgValH1sTrPAlaLysGInGlnArgAlaLysSerArgSerLysArgAspPheI leArgMetArgProSerArgThrSerSerArgAla 323

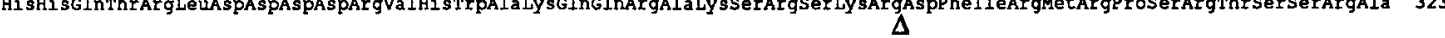
ATGTCGATGGTGGACGCCATGTCCTTTAACGACTCCAAGTGGCCGCAGATGTGGTATCTGAATCGTGGTGGTGGCETGGACATGAATGTGATACCCGCCTGGAAGATGGGCATAACCGGC 1320

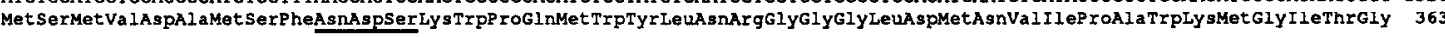
AAGGGCGTGGTGGTGACAATTCTGGATGATGGCCTGGAATCCGATCATCCGGACATACAGGATAACTACGATCCCAAAGCCTCGTACGATGTGAATAGCCACGACGACGATCCGATGCCG 1440

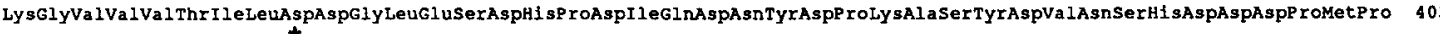
$\star$

CATTACGATATGACGGACTCGAACCGCCATGGAACTCGCTGTGCCGGCGAGGTGGCAGCCACCGCCAACAATTCGTTCTGCGCGGTGGGTATTGCCTACGGCGCCAGTGTGGGCGGAGTC 1560

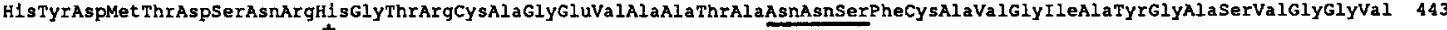
AGGATGCTGGACGGAGACGTCACGGATGCGGTTGAGGCACGGTCGCTGTCGCTGAATCCGCAGCACATTGACATATACAGTGCCTCCTGGGGACCCGATGACGATGGCAAGACGGTGGAC I6B

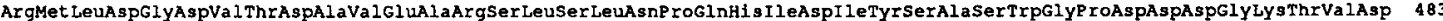

GGACCCGGCGAACTGGCATCGCGCGCCTTTATCGAGGGCACAACTAAGGGACGCGGCGGCAAGGGCAGCATCTTCATATGGGCATCGGGCAATGGTGGGCGGGAGCAGGATAACTGCAAC 1800

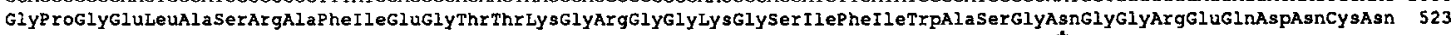
TGCGACGGCTACACGAACTCCATCTGGACGCTGTCCATCTCCAGTGCCACGGAGGAGGGCCATGTGCCCTGGTACTCGGAGAAGTGCAGCTCCACGCTGGCCACCACCTACAGCAGCGGC 1920

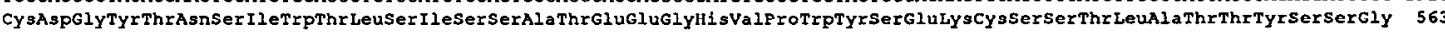
GGGCAGGGCGAGAAGCAGGTGGTCACCACGGACCTGCACCACTCGTGCACTGTCTCCCACACGGGCACCTCGGCGTCGGCCCCGTCGCCGCTGGCATAGCCGCCCTGGTGCTGCAGTCC 2040 GlyGlnGlyGluLYsGInValValThrThrAspLeuHisHisserCysThrValSerHisThrGlyThrSerAlaSerAlaProLeuAlaAlaGlyI leAlaAlaLeuValLeuGlnSer 60 AACCAGAATCTCACCTGGCGCGATCTGCAGCACATTGTTGTGCGCACCGCCAAGCCGGCGAACCTTAAGGACCCCAGCTGGTCACGCAATGGGGTGGGGCGGCGGGTGAGCCACTCCTTT 2160 AsnG InAsnLeuThrTrPArgAspLeuGInHi sI leValValArgThrAla LysProAlaAsnLeuLysAspProSerTrpSerArgAsnglyValGlyArgArgVa1 SerHisSerPhe 643 GGCTACGGATTGATGGACGCCGCCGAGATGGTGCGCGTGGCCCGCAACTGGAAGGCGGTGCCGGAGCAGCAGCGGTGCGAGATTAACGCTCCCCATGTCGACAAGGTCATTCCACCTCGT 228 GIyTyrGlyLeuMetAspAlaAlaGluMetValArgVaiAlaArgAsnTrpLysAlaValProGluGlnGlnArgCysGluIleAsnAlaProHisValAspLysValIleProProArg 683

ACCCATATCACCCTGCAACTGACGGTTAATCACTGTCGATCGGTCAATTACCTGGAGCACGTCCAGGCCAAGATTACGCTAACGTCGCAGAGACGAGGAGACATTCAGCTCTTTTTGAGG 2400 ThrHisIleThrLeuGlnLeuThrValAsnHisCysArgSerValAsnTyrLeuGluHisValGInAla Lys I leThrLeuThrSerGlnArgArgGlyAspI IeGInLeuPheLeuArg 723 TCTCCCGCAAACACCAGTGTCACGCTCCTAACGCCTAGGATACATGACAACTCTCGTTCCGGATTCAATCAATGGCCCTTCATGTCTGTGCACACCTGGGGAGAGTCGCCGCAAGGAAAC 2520 SerProAlaAsnThrSerVal Thr LeuLeuThrProArgI leHisAspAsnSerArgSerGlyPheAsnGInTrpPropheMetSerValHisThrTrpGlyGluSerProGInGIyAsn 763 TGGCAGCTGGAGATCCACAACGAGGGTCGCTATATGGCACAAATCACACAATGGGATATGATATTCTACGGCACCGAAACGCCCGCCCAACCCGATGACGTGGCCAATCCCAGCCAGTCG 2 64 TrPGInLeuGluIleHisAsnGluGlyArgTyrMetAlaGlnIleThrGlnTrpAspMetIlePheTyrGlyThrGluThrProAlaGlnProAspAspValAlaAsnProSerGlnSer 80 AACCAGTTCAATCTGTACGGCAACGATATGGCCCACAATGACGTCGAGTACGATTCCACCGGCCAGTGGAGGATATGCAGCAGGTGGGCGAGGTGGGCATGACCCGAGATCACAGCAAC 2760

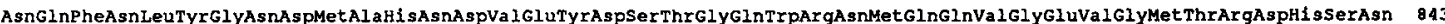

ACCGCCGCGTGCCTTAAGTGGAGCGATCGCAAGTGCTTAGAGTGCAATGACTCCGCCTATATGTTCGAGGACCAGTGCTACGATGTCTGCCCGGTGCACACATATCCATTGGACAAGTTC 2 B8

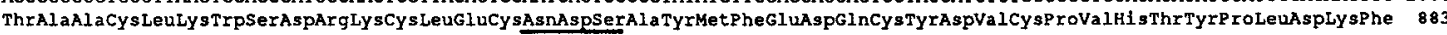
CAAGCAGAGGAGGATGAGCAGGATGACGAGGTGACAAGGGGTCCGGTTAATCCCTACAGCAGCTCCCCCATGGATCATTCCCTGTTGATGTCCAACAGCTTGGATGACAAGCAAGATCCT 3000

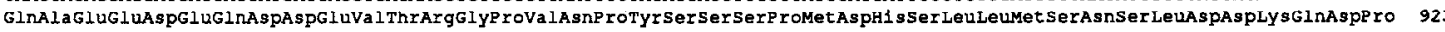

CTGCAGGCGGAGGATCGACGTCGTCGTAGTTCACTCACCCAACTGGTGGAGTTCCTTCTCGGGTCTGTGCCGCCTGCGATCGGAGCTGCTTGGAGTGCTACGGTGCCCTGGCCTCCCAG 3120 LeuGlnAlaGl UASPAIgArgArgArgSerSerLeuTnRGInLeuValGluValProSerArgValCysAlaAlaCysAspArgSerCysLeuGIUCYsTyrGlyAlaLeuAlaSerGin 963

TGCAGCACCTGCTCCCCGGGCAGCCAACTGCGTAAGATCCTGAACGAGACCTTCTGCTATGCCTATGTGGTGCGTAGCACGGGAATGGCCAGTGTGGTGGACATTTCCAAAATGGACGAT 3240 CysSerThrCysSerProGlySerGInLeuArgLysI leLeuAsnGIuThrPheCysTyrAlaTyrVaIValArgSerThrGIYMetAlaSerValVa IAspI leSer LysMetAspAsp 1003 AGAGATACCCÁGCAATATATGACTGGCACAATTGTGCTCCTTTTGGTTTCGGTGATTTTCACCCTGATGGGCGTAGCAGTGGCCGGTGGCATCGTGTATCATCGAAGGGCAATGGCTEGA 3360

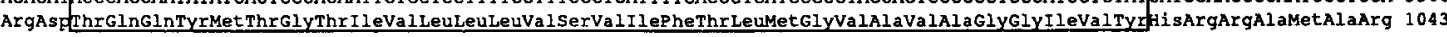
TCCAACGAACTATACTCCCGAGTTTCCCTAGTCCCCGGTGACGAAAGTGACT CTGACGAGGATGAACTGTTTACGGCCCACTTCCCAGGGAGAAAGAGTGGTGTTAATATATATCGCGAT 3480

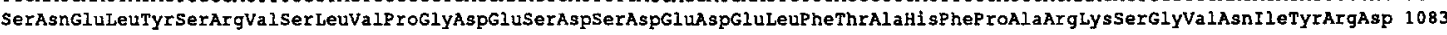
GAAGCGCCCAGCGAAAAGATATTCGAGAAGATGAGATCAGCCACTTGGTACCCTAAATAATCAAAACAAGTTATTAGTTAGGTCATGCATTTAGCCATCCTCATAACCACCAGAAATAT 360 GluAlaProSerGluLYsIlePheGlugluaspgluI leSerHisLeuValPro 
sites of autoproteolytic maturation, a property of subtilisin proteases (Power et al., 1986; Ikemura and Inouye, 1988). Another feature of the predicted dKLIP-1 protein that is conserved with PC2, PC3, and furin is an Arg-Gly-Asp (RGD) motif at amino acid residues 715-717. The RGD sequence, initially identified in fibronectin, is required for integrin binding and cellular adhesion (Pierschbacher and Ruoslahti, 1984).

\section{dKLIP-1 is translocated across membranes}

To determine whether the dKLIP-1 polypeptide, which appeared to lack an amino-terminal signal sequence, could be translocated across microsomal membranes, a series of in vitro translation and translocation experiments were performed. Capped dKLIP-1 RNA was synthesized in vitro and translated in reticulocyte lysate reactions. SDS-PAGE analysis of the translation products showed a predominant protein product of approximately $140 \mathrm{kDa}$ (data not shown), in good agreement with the predicted size $(131 \mathrm{kDa})$ of the dKLIP-1 protein. To test whether the dKLIP-1 translation product was translocated across microsomal membranes, in vitro translation/translocation reactions were performed in the presence of membranes followed by protease treatment with or without detergent. As occurred in the absence of membranes, translation of the dKLIP-1 RNA in the presence of microsomal membranes also resulted in the synthesis of a $140 \mathrm{kDa}$ protein (Fig. 4, lane 1). Treatment of a replicate sample with proteinase $\mathrm{K}$ resulted in a $130 \mathrm{kDa}$ translation product that was protected from protease digestion (Fig. 4 , lane 2). In contrast, when the translation/translocation reactions were protease treated in the presence of detergent to disrupt microsomal membranes, the protein was completely degraded (Fig. 4, lane 3). These results demonstrate that the dKLIP-1 cDNA encodes a $140 \mathrm{kDa}$ protein that can be translocated across microsomal membranes.

\section{dKLIP- 1 is proteolytically active in vivo}

Previously both Kex2p and hfurin were shown to enhance greatly the endoproteolytic conversion of murine pro- $\beta$-NGF to mature $13 \mathrm{kDa} \beta$-NGF in vivo (Bresnahan et al., 1990). To assess the proteolytic activity of $\mathrm{dKLIP}-1$, the protein was coexpressed with pro- $\beta$-NGF in cultured cells using VV vectors, and the conversion of the precursor to mature $\beta$-NGF was analyzed.

Replicate wells of BSC-40 cells were co-infected with a VV recombinant expressing murine pro- $\beta$-NGF (VV:mNGF) and either wild-type VV (VV:WT) or a vaccinia recombinant expressing dKLIP-1 (VV:dKLIP-1). Pulse-labeled products secreted into the medium were immunoprecipitated with an anti$\beta$-NGF polyclonal antiserum and fractionated by SDS-PAGE. The results show that predominantly $40 \mathrm{kDa}$ pro- $\beta$-NGF was secreted from cells co-infected with VV:mNGF and VV:WT (Fig. $5 B$, lane 1). However, when cells were co-infected with VV:mNGF and VV:dKLIP-1, pro- $\beta$-NGF was completely con-

\begin{tabular}{ll}
\hline Table 1. Percentage overall amino acid sequence homology \\
Kex2p homolog & Percentage dKLIP-1 \\
\hline hFurin & $48 / 65$ \\
mPC3 & $46 / 63$ \\
hPC2 & $44 / 62$ \\
Kex2p & $29 / 52$ \\
Subtilisin & $26 / 46$
\end{tabular}

Data are presented as amino acid identities/similarities, the latter defined by evolutionary distance between the amino acids (Gribskov and Burgess, 1986).

verted to mature $13 \mathrm{kDa} \beta$-NGF (Fig. $5 B$, lane 2). To determine the site of cleavage within the precursor, the $13 \mathrm{kDa}$ peptide generated from coexpression of $\mathrm{dKLIP}-1$ and pro- $\beta$-NGF (Fig. $5 B$, lane 2) was transferred to a PVDF membrane and sequenced by Edman degradation (Matsudaira, 1987). Release of ${ }^{35} \mathrm{~S}$ radioactivity was detected in the ninth cycle, which is consistent with the position of the first methionine within mature $\beta$-NGF formed by cleavage of the precursor at $\mathrm{Lys}^{119}-\mathrm{Arg}^{120}$ (Fig. 5C). Thus, dKLIP-1 greatly enhanced conversion of the precursor to $\beta$-NGF peptide, by cleavage at a pair of basic amino acids.

\section{Expression of $d K L I P-1$ transcripts in adult tissues}

To determine the size of the dKLIP-1 hybridizing transcript(s), Northern blots of polyA ${ }^{+}$RNA isolated from adult Drosophila heads and bodies were hybridized to a dKLIP-1 cDNA probe. Transcripts of $4.0,4.5$, and $6.8 \mathrm{~kb}$ were present in both heads and bodies at similar levels (Fig. $6 \mathrm{~A}$ ). However, an $8.4 \mathrm{~kb}$ transcript was preferentially expressed in heads.

Determination of the anatomical distribution of dKLIP-1 transcripts in adult tissues was performed on $8 \mu \mathrm{m}$ horizontal sections of male and female flies hybridized to ${ }^{35} \mathrm{~S}$-labeled riboprobes. Antisense probes bound specifically to a number of tissues (Fig. $7 A, D, F$ ), while control sense-strand probes showed low, nonspecific signals (Fig. $7 C$ ). In the head (Fig. $7 A, B$ ), high levels of hybridization were present in all cortical regions of the brain containing neuronal cell bodies. In contrast, the neuropil, which contains cellular processes, showed only background levels of hybridization. A similar pattern was observed in neuronal cell bodies in the ventral ganglion (data not shown). Lower but significant levels of hybridization were present in the fat body (Fig. $7 A, B$ ).

Strikingly, maternally synthesized dKLIP-1 mRNA was detected in nurse cells and oocytes (Fig. 7D-F). In addition, follicle cells showed low levels of hybridization. The highest overall signals were observed in the oviduct (Fig. $7 D-F$ ). These results demonstrate that dKLIP-1 mRNAs are expressed in the adult CNS, fat body, and female reproductive tissues.

\footnotetext{
Figure 2. Nucleotide sequence of the dKLIP-1 cDNA and deduced protein sequence. $A$, Schematic diagram showing two overlapping cDNA clones, $1 \mathrm{~L}$ and 3, isolated from an adult Drosophila head-specific cDNA library. The approximate length of sequence determined from subcloned fragments is represented by arrows. The lower diagram of the panel shows the ORF (thick line) containing the subtilisin-like catalytic domain (shaded box) in relation to the composite cDNA. The composite dKLIP-1 cDNA was generated by ligating $784 \mathrm{bp}$ from clone $1 \mathrm{~L}$ to $2997 \mathrm{bp}$ from clone 3 using the BamHI $(B)$ restriction site. $B$, The nucleotide sequence of the dKLIP-1 cDNA. An opa repetitive element (nt 257-347) (Wharton et al., 1985) is indicated by single thin underline between the nucleotide and amino acid sequences. Ten potential N-linked glycosylation sites (Asn$\mathrm{X}-\mathrm{Ser} / \mathrm{Thr})$ are indicated by thick underlines. Putative membrane spanning domains are boxed. Open triangles, potential paired basic residue autoproteolytic maturation sites; asterisks, His, Asp, and Ser residues that form the catalytic triad, as well as the Asp residue that stabilizes the transition state complex with the substratc (Kraut, 1977); double underline, RGD sequence important for cellular adhesion; dots, AUUUA motif important for conferring RNA instability. The polyadenylation addition site (nt 3755-3760) is underlined, also.
} 
A

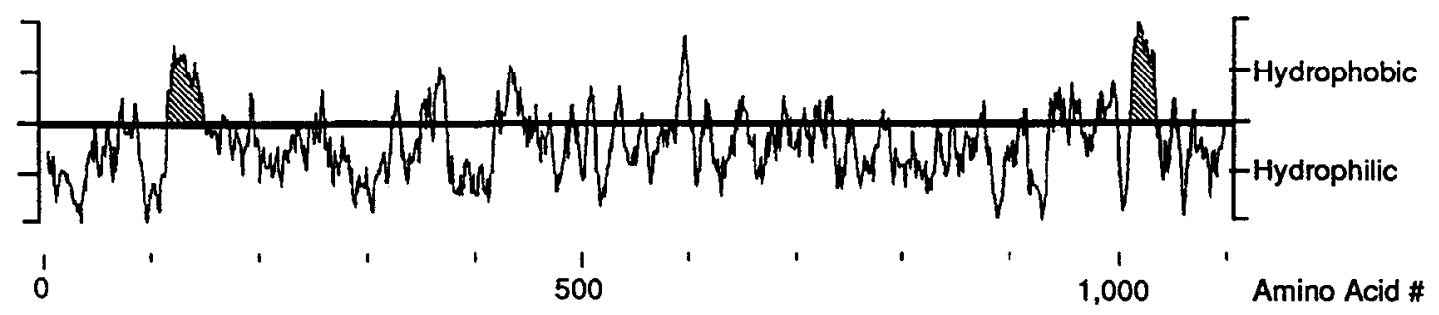

$\mathrm{B}$
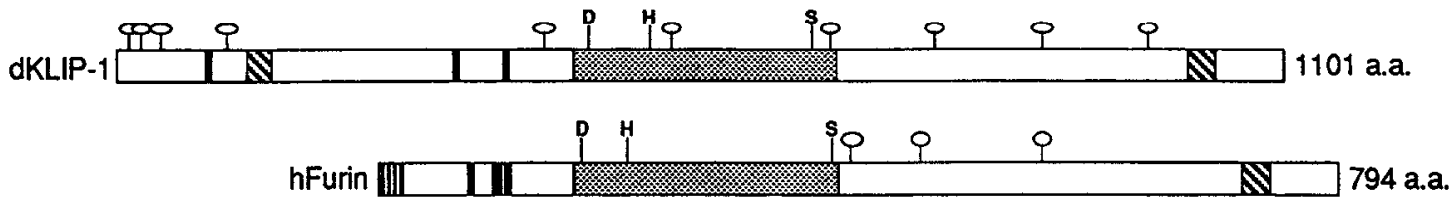

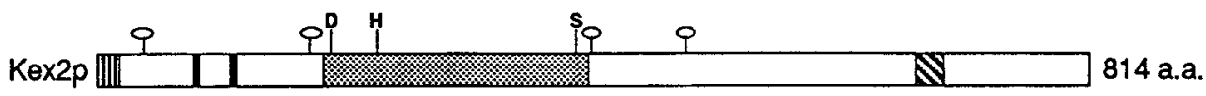

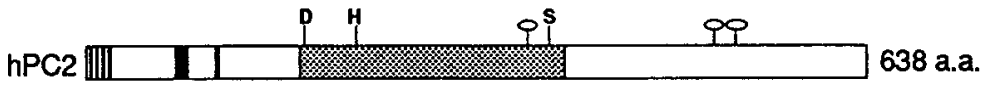

MPC3 IIIL IIIL II I I I I 753 a.a.

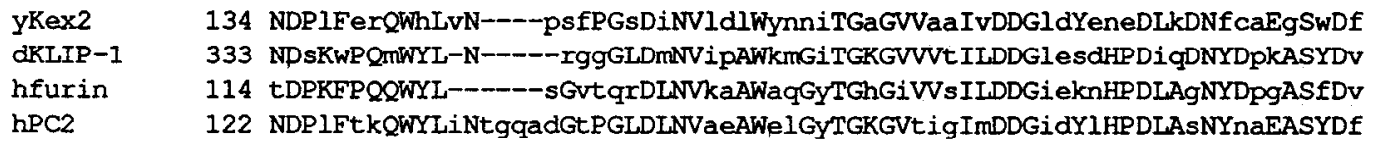

consensus nDpkfpqgWyI-n----g-pglDINV-aW-g-TGkGvv-IIDDG--y-hpDladNyd-eaSyD-

yKex2 198 NdNtnlPkPRIs--DdyHGTRCAGE IAAkkgNNECGVGVgYNAKisGiRiL-sGDiTtedEAaSLiY

dKLIP-1 395 NshDDDPmPhYdmtdsNRHGTRCAGEVAATANNsFCaVGIAYgAsvGGVRMLD-GDVTDAVEARSLSL

hfurin 176 NdqDPDPqPRYTqmDNRHGTRCAGEVAAvANNgVCGVGVAYNAYIGGVRMLD-GeVTDAVEARSIgL

hPC2 190 ssNDPYPYPRYTddwENsHGTRCAGEVsAaANNNICGVGVAYNsKvaGiRMLDqpfmTDi iEAsSiSh

consensus n-dpdP-Pryt-dnrHGTRCAGEvaA-anNnfCgVGvaYnak-gG-RmLd-gdvTdavEArSlsl

yKex2 262 gldvnDIYScSWGPaDDCrhlqGP sDLvkkAlvkGVTeGRdsKGaIyVfASGNGGt IgDNCNyDGYTN

dKLIP-1 462 NPQHIDIYSASWGPdDDGKTVDGP geLAs IAF i GTTKGRGGKGSI I iWASGNGGREqDNCNCDGYTN

hfurin 243 NPnHIhIYSASWGPeDDGKTVDGParLAeeAF frGVsqGRGGIGSIfVWASGNGGREhDsCNCDGYTN

hPC2 258 mPQ1IDIYSASWGPtDnGKTVDGPrDvtIqAmadGVnKGRGGKGSIyVWASGdGG-syDdCNCDGYas

consensus npqhidIYSaSWGP-DdGktvdGP-dla-Af-GvtkGRggkGsI-vwASGnGGre-DnCNcDGYtn

yKex2 330 SIysitIgaidhkdlhPpYSEgCSavmAvTYSSG-sG--Eyi-hssDinGnCsnSHgGTSAaAPIAAG

dKLIP-1 530 SIWTLSISSAT eeGhVPWYSEkCSSTLATTYSSGgQG--EKOVVTTDLhhSCTVSHTGTSASAPLAAG

hfurin 311 SIYTLSISSATqfGnVPWYSEaCSSTLATTYSSGnQn--EKQiVTTDLIqKCTESHTGTSASAPIAAG

hPC2 325 SmwTiSInSAindGrtalYdEsCSSTLAsTfSnGrkmpEagVaTTDLyGnCTIrHsGTSAaAPeAAG

consensus Si-t-sIssat-g-vpwYsE-CSstlAtTySsG-qg--Ekq-vttDl-g-Ct-sHtGTSA-APIAAG

Figure 3. Structural features and sequence alignment analyses of the dKLIP-1 polypeptide with Kex2p-like homologs. A, Kyte and Doolittle hydropathy plot as performed by the PEPPLOT program (Devereux et al., 1984). The two hydrophobic regions that represent potential membrane spanning domains (residues 118-151 and 1006-1036) are hatched. $B$, Schematic diagram showing structural features and relative lengths of dKLIP1, hfurin, yeast Kex $2 \mathrm{p}, \mathrm{hPC} 2$, and mouse PC3 polypeptides. Ovals, potential N-linked glycosylation sites. Signal sequences are marked with striped boxes. Putative TMDs are marked by hatched boxes. Potential paired basic amino acid autoproteolytic cleavage sites (see Discussion) are marked 


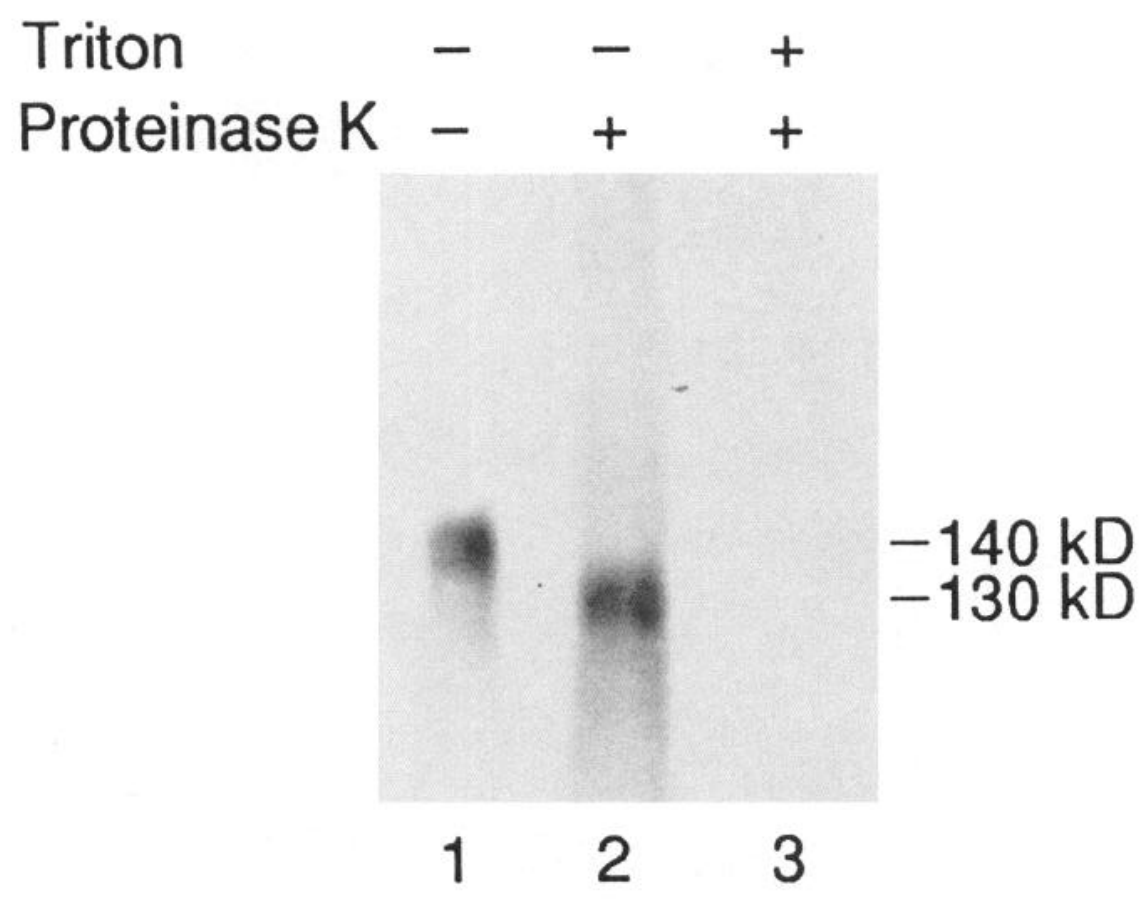

Figure 4. In vitro translocation of dKLIP-1 across microsomal membranes. Replicate tubes containing capped dKLIP-1 transcripts, rabbit reticulocyte lysate, and ${ }^{3} \mathrm{H}$-leucine were incubated for $30 \mathrm{~min}$ at $30^{\circ} \mathrm{C}$. Samples were then incubated in the absence (lane I) or presence of $0.1 \mathrm{mg} / \mathrm{ml}$ proteinase $\mathrm{K}$ alone (lane 2) or with $0.1 \%$ Triton $\mathrm{X}-100$ (lane 3 ) for $45 \mathrm{~min}$ on ice. SDSPAGE analysis of the products and molecular weight standards was performed as described in Materials and Methods.

\section{The expression of $d K L I P-1$ transcripts is developmentally regulated}

Based on the observation that dKLIP-1 mRNA was detected in developing oocytes, expression of the gene during Drosophila development was assessed by Northern blot analysis. PolyA ${ }^{+}$ RNA from embryonic, larval, and pupal stages was blotted and hybridized to a dKLIP-1 cDNA probe (Fig. $8 A$ ). A 4.0 kb RNA transcript was present at the earliest embryonic stages [0-2 hr postfertilization (pf)] (Fig. 8A, lane 1). From 2-10 hr pf, the levels of all dKLIP-1 transcripts were below detection. At 10 $14 \mathrm{hr}$ pf, $4.5,6.8$, and $8.4 \mathrm{~kb}$ transcripts were evident, with the $4.5 \mathrm{~kb}$ form being most abundant (Fig. 8A, lane 4). From $14 \mathrm{hr}$ pf through pupal day 4 , all dKLIP-1 transcript levels were again below detection.

The spatial localization of dKLIP-1 transcripts during embryogenesis was assessed by in situ hybridization of ${ }^{35} \mathrm{~S}$ - and digoxygenin-labeled dKLIP-1 probes to embryonic tissue sections and whole-mounts, respectively. Hybridization was uniformly distributed in stages $1-4(0-2.5 \mathrm{hr}$ pf) embryos (Fig. $9 A, B$ and data not shown). The same photomicrograph shows a stage 10 embryo (5-7 $\mathrm{hr} \mathrm{pf}$ ) that has undergone germ-band extension. Significantly reduced levels of hybridization were present at this stage as expected from Northern blot analysis (described above). This reduction in signal during embryogenesis was observed by stage 5 (cellular blastoderm formation, $2.5-3.25 \mathrm{hr}$ pf) (data not shown). Elevated levels of hybridization reappeared at stage 14 (11.5-13 hr pf), when signals were found in the anal pads, the hindgut, brain and ventral ganglia (Fig. 9C-F). Expression in the anal pads and hindgut was transient, disappearing by stage 16 (13-16 hr pf). In contrast, expression in the CNS continued through stage 16 , when it was found in whole-mount preparations to be in the ventral ganglia in 12 sets of cell clusters located along the ventral midline and ventrolaterally (Fig. 10).

\section{Discussion}

The predicted $d K L I P-1$ polypeptide has unique structural features

The nucleotide sequence of the dKLIP-1 cDNA (Fig. 2) predicted an 1101 amino acid polypeptide containing the conserved Asp, His, and Ser catalytic triad residues characteristic of the subtilisin family of serine endoproteases. dKLIP-1 is structurally similar to a recently identified group of mammalian Kex2like precursor processing endoproteases, furin, $\mathrm{PC} 2$, and $\mathrm{PC} 3$. Comparison of the predicted amino acid sequence of dKLIP-1 with the other Kex2p-like endoproteases revealed a high degree of sequence identity, particularly within the subtilisin-like catalytic domain (Fig. 3B,C; Table 1). In addition, alignment of the catalytic domains resulted in a similar positioning of the C-terminal transmembrane domains in dKLIP-1, hfurin, and Kex $2 p$ as well as shared positions for a small cluster of paired basic amino acids. In the case of Kex $2 p$, one of these cleavage sites represents a proteolytic maturation site (Fuller et al., 1991), which is conserved at nearly the identical position in each of the other endoproteases (Fig. 3B).

There are, however, some marked differences between the

as solid vertical bars. The subtilisin-like catalytic domains, with the catalytic triad residues $(D$, Asp; $H, H i s ; S$, Ser), are shown by the shaded boxes. $C$, Amino acid alignment and consensus sequence of yeast Kex2p ( $y$ Kex2), dKLIP-1, hfurin, and hPC2 catalytic domains using the BESTFIT program (Devereux et al., 1984). *, Residues important for substrate catalysis. The Asn residue involved in transition state hydrogen bonding is conserved by dKLIP-1 but changed to an Asp residue in PC2 (Smeekens and Steiner, 1990). 


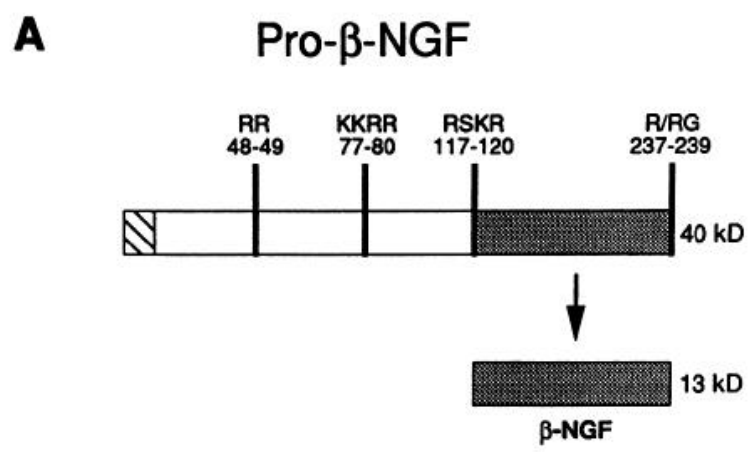

B
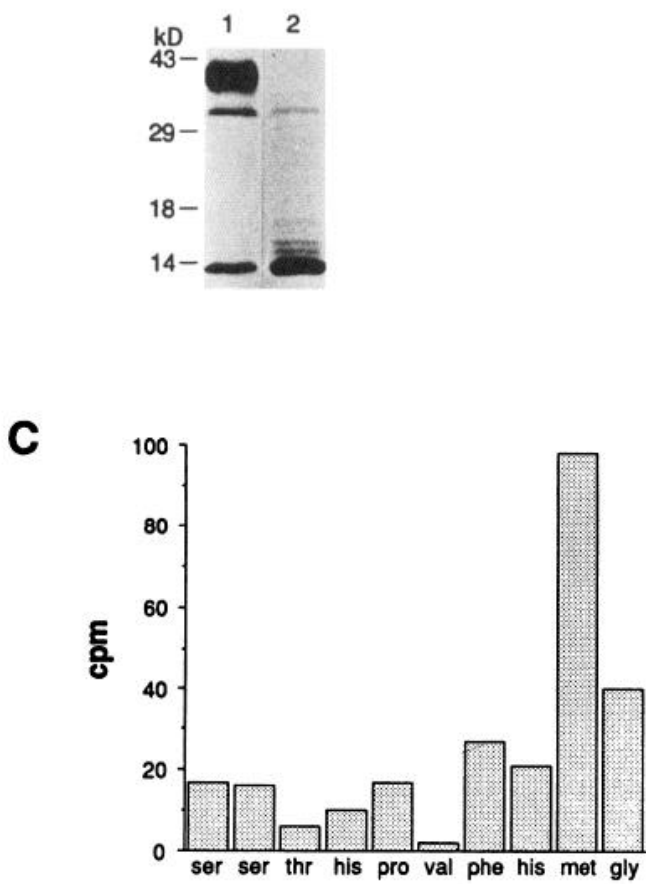

Figure 5. In vivo proteolytic processing of pro- $\beta$-NGF by dKLIP-1. $A$, Schematic diagram showing the precursor structure for the $40 \mathrm{kDa}$ pro- $\beta$-NGF (above) (Darling et al., 1983) as expressed from the VV: mNGF vector and its conversion to $13 \mathrm{kDa} \beta$-NGF (below). The signal sequence is hatched and potential paired basic amino acid cleavage sites are shown as solid vertical lines. B, SDS-PAGE and fluorogram of immunoprecipitated products from pulse-labeled BSC-40 cells co-infected with VV:mNGF plus VV:WT (lane 1) or VV:mNGF plus VV:dKLIP-1 (lane 2). After a 30 min methionine depletion, cells were metabolically labeled with ${ }^{35} \mathrm{~S}$-methionine for $3 \mathrm{hr}$. Equal volumes of media samples were then incubated with a $\beta$-NGF antiserum (Lara et al., 1990), and the immunoprecipitated products were analyzed as described in Materials and Methods. The glycosylated precursor migrates as a broad band of $\sim 35-40 \mathrm{kDa}$, while mature $\beta$-NGF migrates at $13 \mathrm{kDa}$. Products at 14,16 , and $17 \mathrm{kDa}$ are probably processing intermediates. $C$, Sequential Edman degradation analysis of $\beta$-NGF from pulse-labeled BSC40 cells co-infected with VV:mNGF and VV:dKLIP-1. Cells were labeled for $3 \mathrm{hr}$ with ${ }^{35} \mathrm{~S}$-methionine, and immunoprecipitated products were separated by SDS-PAGE. Following transfer to a PVDF membrane (Immobilon-p, Millipore) and autoradiography, the $13 \mathrm{kDa}$ band was subjected to sequential rounds of Edman degradation, from which aliquots were counted by liquid scintillation. The predicted $\mathrm{N}$-terminal sequence of $\beta$-NGF is shown below each sequential cycle.
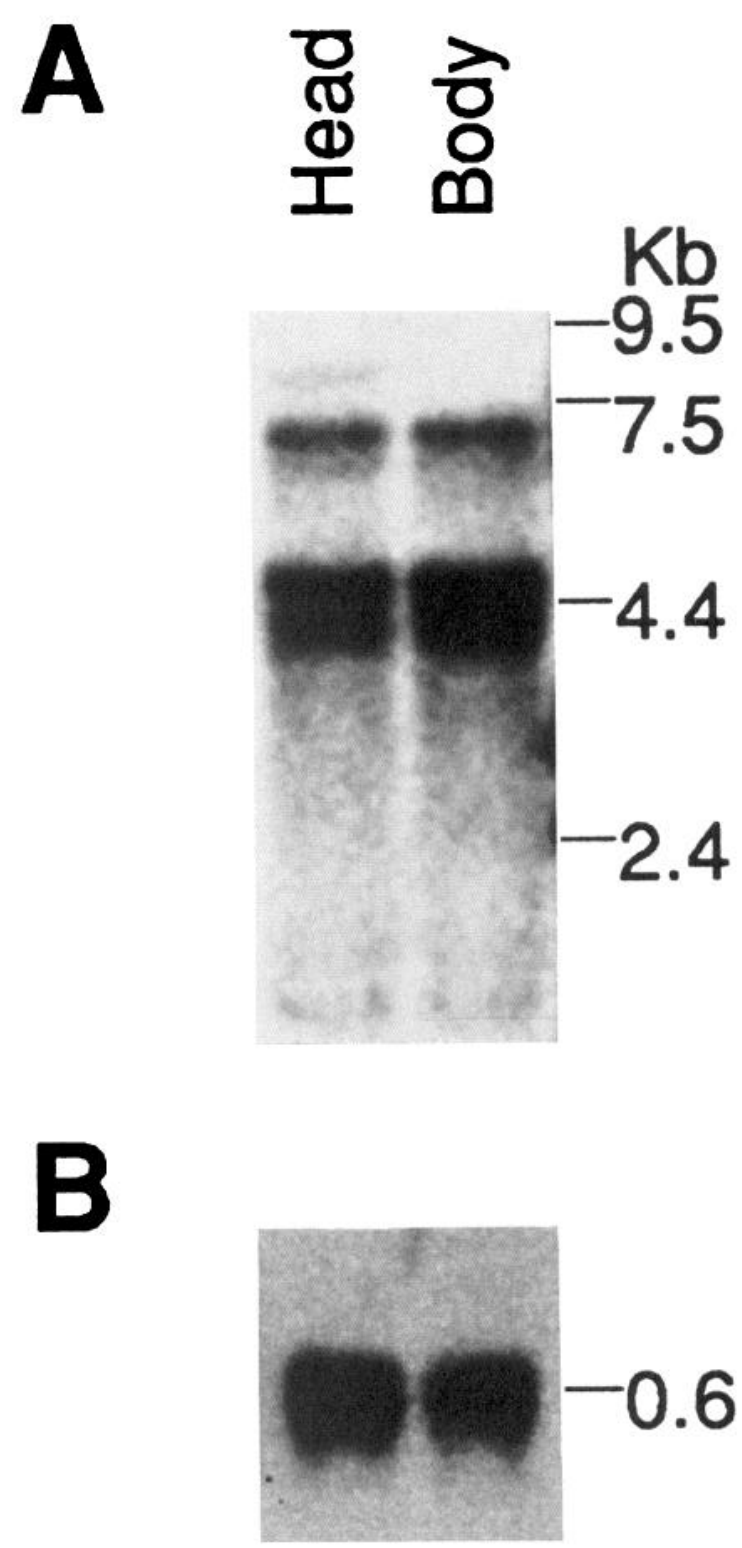

Figure 6. Northern blot analysis of head and body RNA from adult flies. $A$, Polyadenylated RNA (10 $\mu \mathrm{g} /$ lane) from heads and bodies of both sexes was isolated separately, blotted, and hybridized with a ${ }^{32} \mathrm{P}-$ labeled dKLIP-1 cDNA probe as described in Materials and Methods. Size markers are labeled in kilobases. $B$, The same blot stripped and rehybridized with a ${ }^{32} \mathrm{P}$-labeled cDNA probe for the ribosomal protein RP49 to quantitate relative RNA load per lane.

structure of dKLIP-1 and the other Kex2p homologs. First, each of the previously reported homologs is similar in size. In contrast, the translation product encoded by dKLIP- 1 is 287 residues longer than Kex2p. Alignment of the catalytic domain of dKLIP-1 with the catalytic domains of the other Kex2p-like endoproteases suggests that the larger size of dKLIP-1 is apparently due to an extended amino-terminal sequence (Fig. $3 B$ ). Correspondingly, this amino-terminal extended domain of dKLIP-1 contains the least amount of sequence conservation compared with the other Kex2p homologs. Second, whereas each of the other Kex2p-like endoproteases possesses an N-ter- 

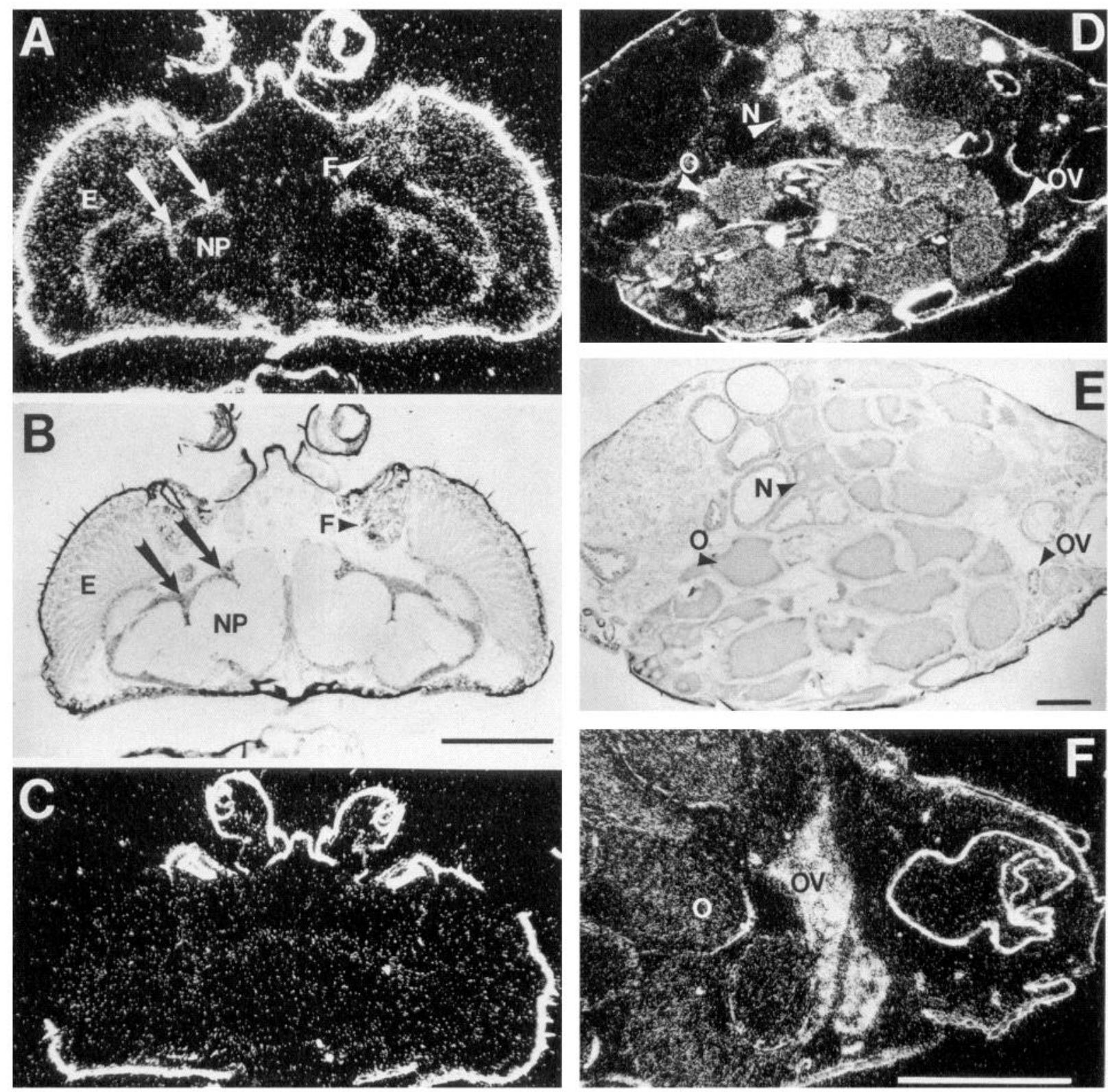

Figure 7. In situ hybridization to adult head and ovary sections. Anterior is up in $A-C$, to the left in $D-F$. $A$ and $B$, Dark-field and bright-field images, respectively, showing localization of dKLIP-1 mRNA using an antisense probe in a female head with high levels of hybridization in cortical brain regions (arrows), and the fat body $(F)$. The central neuropil $(N P)$ of the brain has a background level of signal (compare with $C$ ). Low levels of hybridization in the eyes $(E)$ are slightly above background and therefore are not a reliable indication of dKLIP-1 message. The high levels of signal outlining the head and abdomen result from nonspecific binding of the probe to the extracellular cuticle and are a common artifact of the preparation. $C$, Dark-field image of an adjacent head section hybridized with a sense-strand dKLIP-1 probe as a control shows low or background levels of hybridization. $D$ and $E$, Dark-field and bright-field images of a female abdomen hybridized with antisense probe showing localization of dKLIP-1 message to the ovaries including nurse cells $(N)$, oocytes $(O)$, and the oviduct $(O V)$. F, High-magnification image of the region surrounding the oviduct $(O V)$, where the highest levels of expression are detected. Scale bars, $200 \mu \mathrm{m}$.

minal signal sequence to permit transit into the secretory pathway, dKLIP-1 lacks this domain. Nonetheless, when translated in vitro, dKLIP-1 was translocated across microsomal membranes (Fig. 4). In addition, coexpression of dKLIP-1 in vivo resulted in the complete conversion of pro- $\beta$-NGF at $-\mathrm{Lys}^{119}$ $\mathrm{Arg}^{120}$ - in the secretory pathway (Fig. 5B,C). Possibly, the internal hydrophobic domain (residues 118-151) unique to dKLIP1 facilitates its translocation into the lumen of the endoplasmic reticulum.

\section{dKLIP-1 expression is developmentally regulated}

In situ studies of adult fly sections detected dKLIP-1 transcripts in ventral ganglia and brain as well as the fat body (Fig. 7A,B). However, most striking was the detection of dKLIP-1 transcripts in ovaries (Fig. $7 D-F$ ). Expression in developing oocytes and nurse cells demonstrated that these dKLIP-1 transcripts are of maternal origin and implies a role for dKLIP-1 in early embryogenesis, prior to zygotic transcription. 
Figure 8. Temporal expression of dKLIP-1 transcripts during Drosophila development. $A$, Polyadenylated RNA $(10 \mu \mathrm{g} /$ lane $)$ isolated from indicated developmental stages grown at $25^{\circ} \mathrm{C}$ was blotted and hybridized with ${ }^{32} \mathrm{P}$-labeled dKLIP-1 cDNA probe. The adult RNA (lane 11) was a mixture of the RNA analyzed in the adult head/body blot (Fig. 6). Size standards are indicated in kilobases to the left. B, Control hybridization using RP49 as an internal standard for quantitative RNA load per lane.
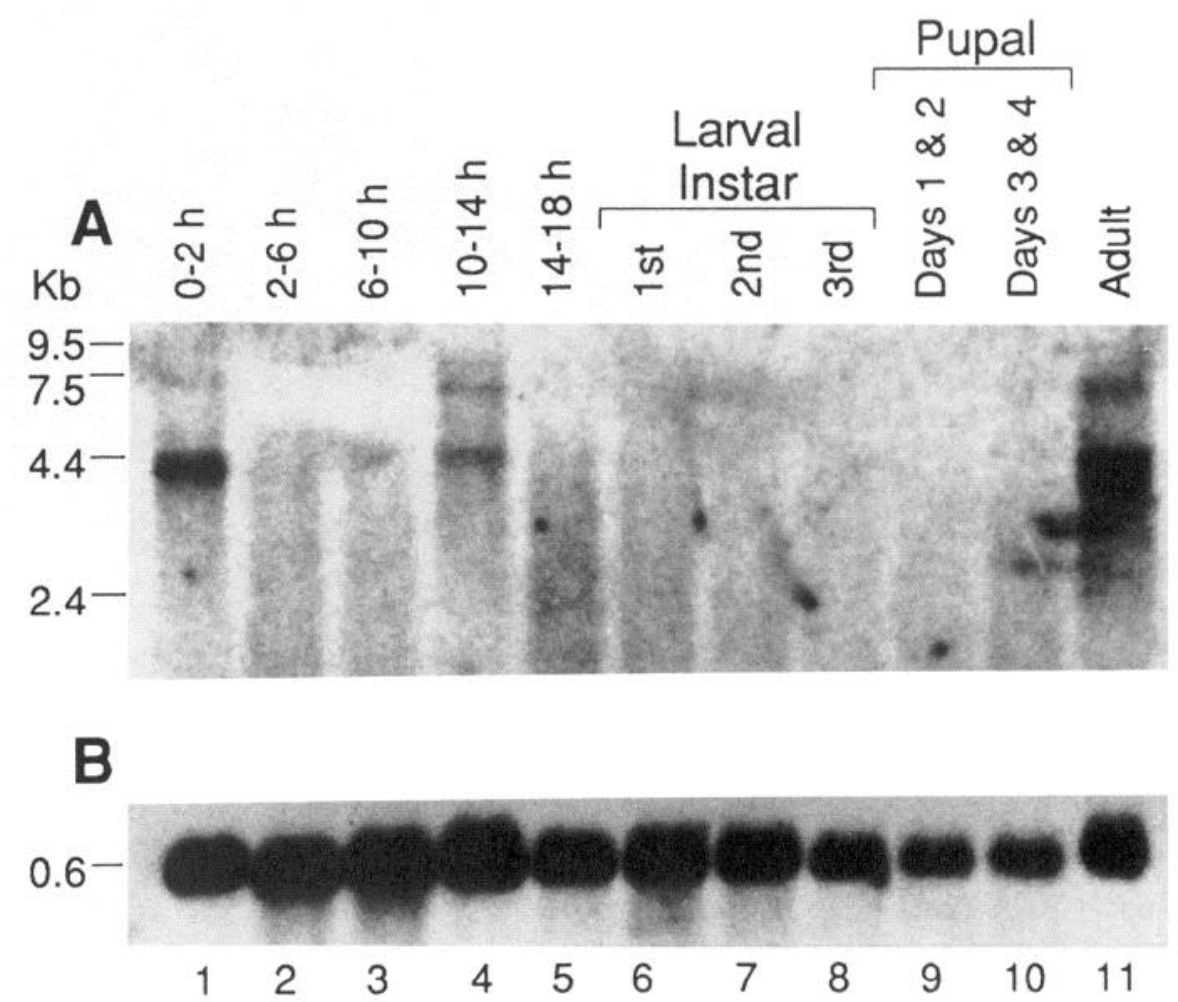

Detection of dKLIP-1 RNA in 0-2 hr embryos (Figs. $8 A$, lane $1 ; 9 A, B)$ is associated with the expression of a variety of transcripts and proteins involved in the determination of polarity and positional information in the embryo (Ingham, 1988). Later in development, dKLIP-1 transcripts are expressed in embryos at discrete times and restricted to specific cell populations. After germ-band shortening (10-14 hr), RNA levels were detected in the hindgut, ventral ganglia, brain, and anal pads (Figs. $9 C-F$, 10). During this time, the hindgut lengthens and the neuropil forms in the nervous system.

After stage 4, dKLIP-1 transcripts appeared to be rapidly degraded (Fig. $8 A$, lanes 1,2 ). The loss of signal suggests that dKLIP-1 expression is developmentally regulated, in part, by rapid turnover of its RNA. dKLIP-1 and several mammalian mRNAs (e.g., GM-CSF, c-fos, and c-myc) possess a motif (AUUUA) repeated within their 3' UTRs (Shaw and Kamen, 1986; Fig. 2). Mammalian transcripts possessing this motif are selectively and rapidly degraded.

In addition to the AUUUA sequence in the 3' UTR, the dKLIP-1 transcript contains an opa element (Fig. 2, nt 258$347)$, a repeated trinucleotide $\left(\mathrm{CAX}_{n}\right)$ located in the nonconserved amino-terminal domain of the protein coding sequence (Wharton et al., 1985). Although the function of this element is unknown, opa sequences are present in several developmentally regulated Drosophila genes including notch, antennapedia, and dorsal (Grabowski et al., 1991).

\section{Roles for serine proteases in early fly development and potential substrates for $d K L I P-1$}

Numerous studies have demonstrated that trypsin-like activities and other proteins with homology to mammalian serine proteases have essential roles in fly development. During larval metamorphosis, for example, imaginal disk eversion appears to be regulated by a trypsin-like protease activity since trypsin treatment of disks in culture increased the rate of eversion (PinoHeiss and Schubiger, 1989). Conversely, trypsin inhibitors retarded this process. During early embryogenesis, dorsal-ventral axis formation is mediated by a biochemical pathway that includes the products of two genetic loci, easter and snake (DeLotto and Spierer, 1986; Chasan and Anderson, 1989). The products of both loci are structurally related to mammalian trypsin/chymotrypsin serine proteases and include the His, Asp, and Ser residues forming the characteristic catalytic triad (as opposed to the Asp, His, and Ser order in the subtilisin-like triad) (Neurath, 1984).

Unlike the trypsin/chymotrypsin family of endoproteases, the Kex2p-like subtilisin endoproteases specifically cleave substrates on the $\mathrm{C}$-terminal side of paired basic amino acids (-LysArg-,-Arg-Arg-) in the secretory pathway (Thomas et al., 1988a, 1991; Fuller et al., 1989a; Mizuno et al., 1989). Analysis of mutant substrates (Bentley et al., 1986; Yoshimasa et al., 1988, 1990; Yoshiro and Webster, 1988) suggests that an additional feature of the cleavage site commonly found in many precursor proteins is an arginine located four residues $(-4 \mathrm{Arg}) \mathrm{N}$-terminal to the paired basic cleavage site (-Arg-X-Lys/Arg-Arg-). Indeed, studies in vitro indicate a strong preference by dKLIP-1 for synthetic peptide substrates containing a pair of basic residues and a $-4 \mathrm{Arg}$ (J. S. Hayflick and G. Thomas, unpublished observations).

Several developmentally important Drosophila precursor proteins expressed coincident with dKLIP-1 during embryogenesis possess the -Arg-X-Lys/Arg-Arg- cleavage site motif and are thus candidate substrates for a Kex2p-like endoprotease such as dKLIP-1. These include the gene products of the decapen- 

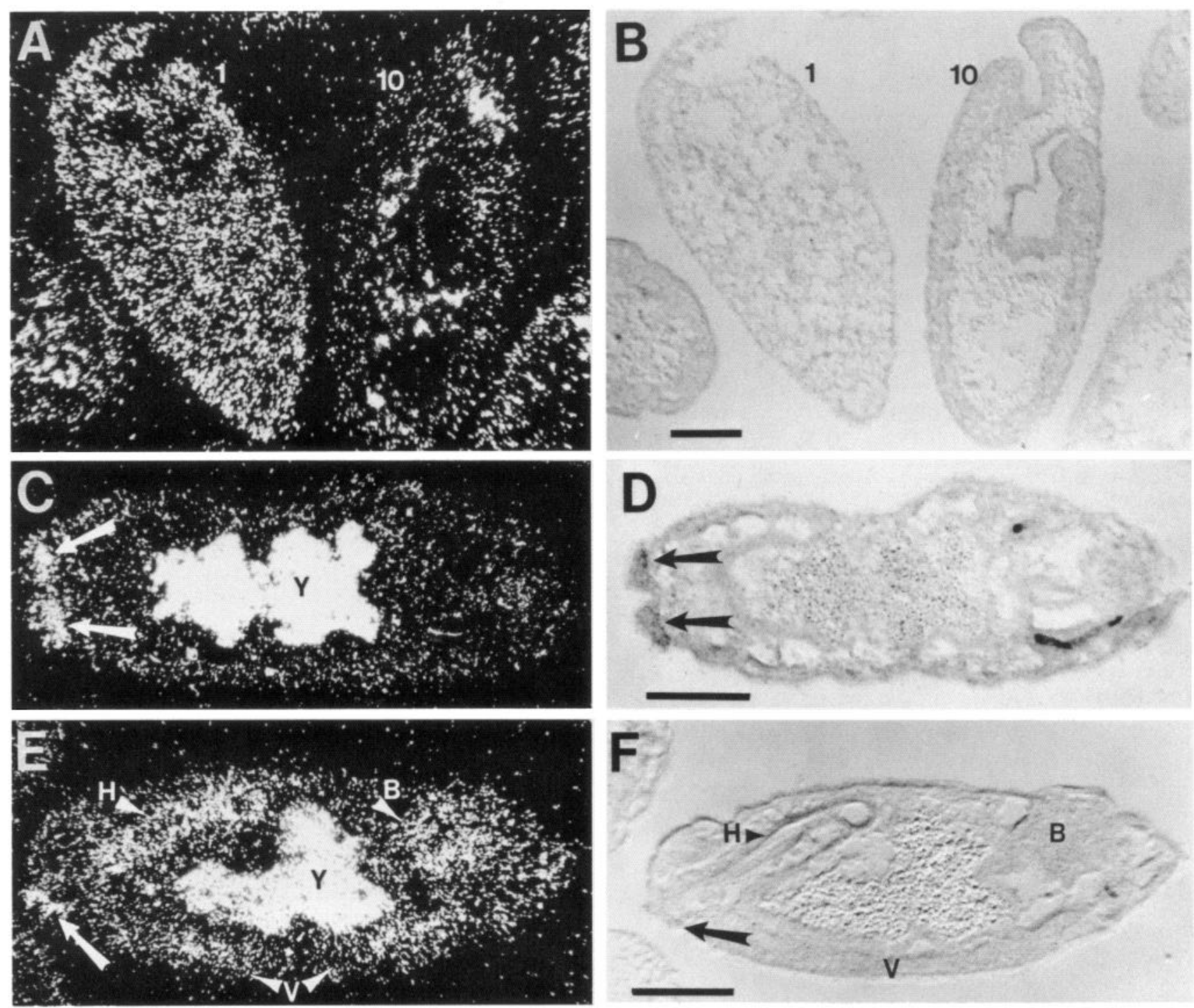

Figure 9. In situ localization of dKLIP-1 transcripts in $8 \mu \mathrm{m}$ sections of embryos. $A$ and $B$, Dark-field and bright-field images of an early nuclear cleavage (stage 1; ventral, right; anterior, down) embryo and a germ-band extended (stage 10; ventral, left; anterior, up) embryo. Note the elevated signal in the stage 1 embryo compared to the background levels seen in the stage 10 embryo. $C$ and $D$, Dark-field and bright-field images of a horizontal section through a stage 14 embryo (anterior, right) showing signals located in the anal pads (arrows). $E$ and $F$, Dark-field and brightfield images of a parasagital section through a stage 14 embryo (ventral, down; anterior, right) showing signals in the brain $(B)$, hindgut $(H)$, ventral ganglia ( $V$ ), and anal pads (arrows). The central bright material in $C$ and $E$ is yolk $(Y)$ and is an artifact of the preparation. Scale bars, $100 \mu \mathrm{m}$.

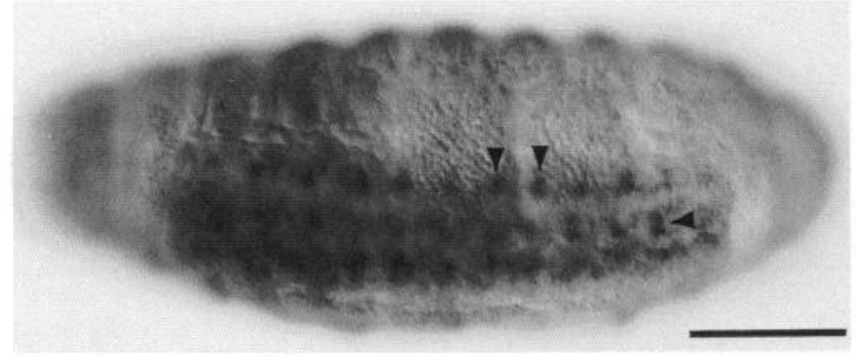

Figure 10. In situ hybridization detection in a stage 16 whole-mount embryo using an antisense digoxigenin-labeled probe. The signals are localized to three rows of cell bodies, two lateral (arrowheads) and one medial, in the ventral ganglia (anterior, left). Scale bar, $100 \mu \mathrm{m}$. taplegic and tolloid loci as well as an insulin-like pro-receptor protein (Nishida et al., 1986; Padgett et al., 1987; Shimell et al., 1991).

Biochemical studies based on expression of decapentaplegic translation product (dpp) in Schneider 2 (S2) cells resulted in the cleavage of pro-dpp on the $\mathrm{COOH}$-terminal side of a single basic residue with a -4 Arg (Panganiban et al., 1990). A conserved paired basic residue site with a -4 Arg (-Arg-Asn-LysArg-), proximal to the cleavage site in pro-dpp was not utilized as it is in the structurally related pro-TGF $\beta 1$ and the inhibin precursors (Derynck et al., 1985; Mason et al., 1985). It has not been reported if processing of pro-DPP in S2 cells mimics the endogenous processing in the developing embryo. Studies examining the ability of dKLIP-1 to process these precursors are currently underway. 
The cloning and characterization of the Drosophila Kex $2 p$ homolog dKLIP-1 now afford the exploitation of Drosophila genetics to elucidate the role of this endoprotease and its metazoan homologs in vivo.

Note added in proof. The DNA sequence reported in this paper has been deposited in the Genbank database (accession number M81431). The dKLIP-1 gene localization and related molecular cloning information have been deposited in the Drosophila Genmaps database under KexZ-like endoprotease-1.

\section{References}

Angerer LM, Angerer RC (1981) Detection of poly-A RNA in sea urchin eggs and embryos by quantitative in situ hybridization. Nucleic Acids Res 9:2819-2840.

Bathurst IC, Brennan SO, Carrell RW, Cousens LS, Brake AJ, Barr PJ (1987) Yeast Kex2 protease has the properties of a human proalbumin converting enzyme. Science 235:348-350.

Benjannet S, Rondeau N, Day R, Chretien M, Seidah NG (1991) PC1 and $\mathrm{PC} 2$ are proprotein convertases capable of cleaving proopiomelanocortin at distinct pairs of basic residues. Proc Natl Acad Sci USA 88:3564-3568.

Bentley AK, Ree DJG, Rizza C, Brownlee GG (1986) Defective propeptide processing of blood clotting factor IX caused by mutation of arginine to glutamine at position -4 . Cell 45:343-348.

Bresnahan PA, Leduc R, Thomas L, Thorner J, Gibson HL, Brake AJ, Barr PJ, Thomas G (1990) Human fur gene encodes a yeast Kex2like endoprotease that cleaves pro-beta-NGF in vivo. J Cell Biol 111: 2851-2859.

Campos-Ortega JA, Hartenstein V (1985) The embryonic development of Drosophila melanogaster. Berlin: Springer.

Cathala G, Savouret J-F, Mendez B, West BL, Karin M, Martial JA, Baxter JD (1983) A method for isolation of intact, translationally active ribonucleic acid. DNA 2:329-335.

Cavener D (1987) Comparison of the consensus sequence flanking the translational start sites in Drosophila and vertebrates. Nucleic Acids Res 15:1353-1361.

Chance RE, Ellis RM, Bromer WW (1968) Porcine proinsulin: characterization and amino acid scquencc. Science 161:165-167.

Chasan R, Anderson KV (1989) The role of easter, an apparent serine protease, in organizing the dorsal-ventral pattern of Drosophila embryo. Cell 56:391-400.

Chen EY, Seeburg PH (1985) Supercoil sequencing: a fast and simple method for sequencing plasmid DNA. DNA 4:165-170.

Chretien M, Li CH (1967) Isolation, purification, and characterization of $\gamma$-lipotropic hormone form sheep pituitary glands. Can J Biochem 45:1163-1174.

Darling TLJ, Petrides PE, Beguin P, Frey P, Shooter EM, Selby M, Rutter WJ (1983) The biosynthesis and processing of proteins in the mouse $7 \mathrm{~S}$ nerve growth factor complex. Cold Spring Harbor Symp Quant Biol 48:427-434.

DeLotto R, Spierer P (1986) A gene required for the specification of dorsal-ventral pattern in Drosophila appears to encode a serine protease. Nature 323:688-692.

Derynck R, Jarrett JA, Chen EY, Eaton DH, Bell JR, Assoian RK, Roberts AB, Sporn MB, Goeddel DV (1985) Human transforming growth factor- $\beta$ complementary DNA sequence and expression in normal and transformed cells. Nature 316:701-705.

Devereux J, Haeberli P, Smithies O (1984) A comprehensive set of sequence analysis programs for the VAX. Nucleic Acids Res 12:387395.

Douglass JD, Civelli O, Herbert E (1984) Polyprotein gene expression: generation of diversity of neuroendocrine peptides. Annu Rev Biochem 53:665-715.

Feinberg AP, Vogelstein B (1983) A technique for radiolabeling DNA restriction fragments to high specific activity. Anal Biochem 132:612.

Fuller RS, Brake A, Thorner J (1986) The Saccharomyces cerevisiae Kex 2 gene, required for processing prepro-alpha-factor, encodes a calcium-dependent endopeptidase that cleaves after Lys-Arg and ArgArg sequences. In: Microbiology (Leive L, ed), pp 273-278. Washington, DC: American Society for Microbiology.

Fuller RS, Sterne RE, Thorner J (1988) Enzymes required for yeast prohormone processing. Annu Rev Physiol 50:345-362.
Fuller RS, Brake A, Thorner J (1989a) Yeast prohormone processing enzyme (Kex2 gene product) is a $\mathrm{Ca}^{2+}$-dependent serine protease. Proc Natl Acad Sci USA 86:1434-1438.

Fuller RS, Brake A, Thorner J (1989b) Intracellular targeting and structural conservation of a prohormone-processing endoprotease. Science 246:482-485.

Fuller RS, Brenner C, Gluschankof P, Wilcox CA (1991) The yeast prohormone-processing Kex 2 protease, an enzyme with specificity for paired basic residues. Adv Life Sci, in press.

Grabowski DT, Carney JP, Kelley MR (1991) A Drosophila genc containing the opa repetitive element is exclusively expressed in adult male abdomens. Nucleic Acids Res 19:1709.

Gribskov M, Burgess RR (1986) Sigma factors from E. coli, B. subtilis, phage SPO1, and T4 are homologous proteins. Nucleic Acids Res 14: 6745-6763.

Hafen E, Levine M (1986) The localization of RNAs in Drosophila tissue sections by in situ hybridization. In: Drosophila: a practical approach (Roberts DB, ed), pp 139-157. Oxford: IRL.

Harlow E, Lane D (1988) Antibodies: a laboratory manual, p 449. Cold Spring Harbor, NY: Cold Spring Harbor Laboratory.

Hatsuzawa K, Hosaka M, Nakagawa T, Nagase M, Shoda A, Murakami K, Nakayamas K (1990) Structure and expression of mouse furin, a yeast Kex2-related protease. J Biol Chem 265:22075-22078.

Hruby DE, Thomas G, Herbert E, Francke CA (1986) Usc of vaccinia virus as a neuropeptide expression vector. Methods Enzymol 124: 295-309.

Ikemura $\mathbf{H}$, Inouye $\mathbf{M}$ (1988) In vitro processing of pro-subtilisin produced in Escherichia coli. J Biol Chem 263:12959-12963.

Ingham PW (1988) The molecular genetics of embryonic pattern formation in Drosophila. Nature 335:25-34.

Julius DA, Brake A, Blair L, Kunisawa R, Thorner J (1984) Isolation of the putative structural gene for the lysine-arginine-cleaving endopeptidase required for processing of yeast prepro-alpha-factor. Cell 37:1075-1089.

Kraut J (1977) Serine proteases: structure and mechanism of catalysis. Annu Rev Biochem 46:331-358.

Kreig PA, Melton DA (1987) In vitro RNA synthesis with SP6 RNA polymerase. Methods Enzymol 155:397-409.

Kyte J, Doolittle RF (1982) A simple method for displaying the hydropathic character of a protein. J Mol Biol 157:105-132.

Laemmli UK (1970) Cleavage of structural proteins during the assembly of the head of bacteriophage T4. Nature 227:680-685.

Lara HE, McDonald JK, Ojeda SR (1990) Involvement of nerve growth factor in female sexual development. Endocrinology 126:364-375.

Leibowitz MJ, Wickner RB (1976) A chromosomal gene required for killer plasmid expression, mating and spore maturation in Saccharomyces cerevisiae. Proc Natl Acad Sci USA 73:2061-2065.

Mason AJ, Hayflick JS, Ling N, Esch F, Ueno N, Ying S-Y, Guillemin R, Niall H, Seeburg PH (1985) Complimentary DNA sequences of ovarian follicular fluid inhibin show precursor structure and homology with transforming growth factor- $\beta$. Nature 318:659-663.

Matsudaira P (1987) Sequence from picomole quantitics of proteins electroblotted onto polyvinylidene difluoride membranes. J Biol Chem 262:10035-10038.

McCune JM, Rabin LB, Feinberg MB, Lieberman M, Kosek JC, Reyes GR, Weissman IR (1988) Endoproteolytic cleavage of gp160 is required for the activation of human immunodeficiency virus. Cell 53: 55-67.

Mitchison TJ, Sedat J (1983) Localization of antigenic determinants in whole Drosophila embryos. Dev Biol 99:261-264.

Mizuno K, Nakamura T, Oshima T, Tanaka S, Matsuo H (1988) Yeast Kex2 gene encodes an endopeptidase homologous to subtilisin-like serine proteases. Biochem Biophys Res Commun 156:246-254.

Mizuno K, Nakamura T, Oshima T, Tanaka S, Matsuo H (1989) Characterization of Kex2-encoded endopeptidase from yeast Saccharomyces cerevisiae. Biochem Biophys Res Commun 159:305-311.

Neurath H (1984) Evolution of proteolytic enzymes. Science 224:350357.

Nishida Y, Hata M, Nishizuka Y, Rutter WJ, Ebina Y (1986) Cloning of a Drosophila cDNA encoding a polypeptide similar to the human insulin receptor precursor. Biochem Biophys Res Commun 141:474481.

Padgett RW, St Johnston RD, Gelbart WM (1987) A transcript from a Drosophila pattern gene predicts a protein homologous to the transforming growth factor- $\beta$ family. Nature 325:81-84.

Panganiban GEF, Rashka KE, Neitzel MD, Hoffmann M (1990) Bio- 
chemical characterization of the Drosophila dpp protein, a member of the transforming growth factor- $\beta$ family of growth factors. Mol Cell Biol 10:2669-2677.

Pierschbacher MD, Ruoslahti E (1984) Cell attachment activity of fibronectin can be duplicated by small synthetic fragments of the molecule. Nature 309:30-33.

Pino-Heiss S, Schubiger G (1989) Extracellular protease production by Drosophila imaginal discs. Dev Biol 132:282-291.

Power SD, Adams RM, Wells JA (1986) Secretion and autoproteolytic maturation of subtilisin. Proc Natl Acad Sci USA 83:3096-3100.

Proudfoot NJ, Brownlee GG (1976) 3' non-coding region sequences in eukaryotic messenger RNA. Nature 263:211-214.

Roberts DB (1986) Basic Drosophila care and techmiques. In: Drosophila: a practical approach (Roberts DB, ed), pp 1-38. Oxford: IRL.

Rubin GM (1988) Drosophila melanogaster as an experimental organism. Science 240:1453-1459.

Saiki RK, Gelfand DH, Stoffel S, Scharf SJ, Higuchi R, Horn GT, Mullis KB, Erlich HA (1988) Primer-directed enzymatic amplification of DNA with a thermostable DNA polymerase. Science 239:487-491.

Schalken JA, Roebroek AJM, Oomen PPCA, Wagenaar SS, Debruyne FMJ, Bloemers HPJ, Van de Ven WJM (1987) fur gene expression as a discriminating marker for small cell and non-small cell lung carcinomas. J Clin Invest 80:1545-1549.

Scheller RH, Jackson JF, McAllister LB, Rothman BS, Mayeri E, Axel $R$ (1983) A single gene encodes multiple neuropeptides mediating a stereotyped behavior. Cell 32:7-22.

Seidah NG, Gaspar L, Mion P, Marcinkiewič M, Mbikay M, Chretien M (1990) cDNA sequence of two distinct pituitary proteins homologous to $K e x 2$ and fur gene products: tissue-specific mRNAs encoding candidates for pro-hormone processing proteinases. DNA Cell Biol 9:415-424.

Seidah NG, Marcinkiewicz M, Benjannet S, Gaspar L, Beaubien G, Mattei MG, Lazure C, Mbikay M, Chretien M (1991) Cloning and primary sequence of a mouse candidate prohormone convertase $\mathrm{PCl}$ homologous to PC2, furin and Kex2: distinct chromosomal localization and messenger RNA distribution in brain and pituitary compared to PC2. Mol Endocrinol 5:111-122.

Shaw G, Kamen $R$ (1986) A conserved AU sequence from the $3^{\prime}$ untranslated region of GM-CSF mRNA mediates selective messenger RNA degradation. Cell 46:659-667.

Shimell MJ, Ferguson EL, Childs SR, O'Conner MB (1991) The Drosophila dorsal-ventral patterning gene tolloid is related to human bone morphogenetic protein 1. Cell 67:469-481.

Smeekens SP, Steiner DF (1990) Identification of a human insulinoma cDNA encoding a novel mammalian protein structurally related to the yeast dibasic processing protease Kex2. J Biol Chem 265:29973000 .

Smeekens SP, Avruch AS, LaMendola J, Chan SJ, Steiner DF (1991) Identification of a cDNA encoding a second putative prohormone convertase related to PC2 in AtT20 cells and islets of Langerhans. Proc Natl Acad Sci USA 88:340-344.

Sossin WS, Fisher JM, Scheller RH (1989) Cellular and molecular biology of neuropeptide processing and packaging. Neuron 2:14071417.

Steiner DF, Cunningham D, Spigelman L, Aten B (1967) Insulin biosynthesis: evidence for a precursor. Science 157:697-700.
Tabor S, Richardson CC (1987) DNA sequence analysis with a modified bacteriophage 17 DNA polymerase. Proc Natl Acad Sci USA $84: 4767-4771$.

Tautz D, Pfeifle C (1989) A non-radioactive in situ hybridization method for the localization of specific RNAs in Drosophila embryos reveals translational control of the segmentation gene hunchback. Chromosoma 98:81-85.

Thomas G, Thorne BA, Thomas L, Allen RG, Hruby DE, Fuller R, Thorner J (1988a) Yeast Kex2 endopeptidase correctly cleaves a neuroendocrine prohormone in mammalian cells. Science 241:226230.

Thomas G, Thorne BA, Hruby DE (1988b) Gene transfer techniques to study neuropeptide processing. Annu Rev Physiol 50:323-332.

Thomas L, Leduc R, Thorne BA, Smeekens SP, Steiner DF, Thomas G (1991) Kex2-like endoproteases PC2 and PC3 accurately cleave a model prohormone in mammalian cells: evidence for a common core of neuroendocrine processing enzymes. Proc Natl Acad Sci USA 88:5297-5301.

van den Ouweland AM, van Duijnhoven HLP, Keizer GD, Dorssers LCJ, Van de Ven WJM (1990) Structural homology between the human fur gene product and the subtilisin-like protease encoded by yeast Kex2. Nucleic Acids Res 18:664.

van de Ven WJM, Voorberg J, Fontijn R, Pannekoek H, van den Ouweland AMW, van Duijnhoven HLP, Roebroek AJM, Siezen RJ (1990) Furin is a subtilisin-like proprotein processing enzyme in higher eukaryotes. Mol Biol Rep 14:265-275.

Wada K, Aota S, Tsuchiya R, Ishibashi F, Gojobori T, Ikemura $T$ (1990) Codon usage tabulated from the GenBank genetic sequence data. Nucleic Acids Res 18:2367-2412.

Weeks DL, Melton DA (1987) A maternal mRNA localized to the vegetal hemisphere in Xenopus eggs codes for a growth factor related to TGF- $\beta$. Cell $51: 861-867$.

Wharton KA, Yedvobnick B, Finnerty VG, Artavanis-Tsakonas S (1985) opa: a novel family of transcribed repeats shared by the Notch locus and other developmentally regulated loci in $D$. melanogaster. Cell 40 : $55-62$.

Wise RJ, Barr PJ, Wong PA, Kiefer MC, Brake AJ, Kaufman RJ (1990) Expression of a human proprotein processing enzyme: correct cleavage of the von Willebrand factor precursor at a paired basic amino acid site. Proc Natl Acad Sci USA 87:9378-9382.

Yanisch-Perron C, Vieira J, Messing J (1985) Improved M13 phage cloning vectors and host strains: nucleotide sequences of the M13mp18 and pUC19 vectors. Gene 33:103-121.

Yoshimasa Y, Seino S, Whittaker J, Kakehi T, Kosaki A, Kuzuya H, Imura H, Bell GI, Steiner DF (1988) Insulin-resistant diabetes due to a point mutation that prevents insulin proreceptor processing. Science 240:784-787.

Yoshimasa Y, Paul J, Whittaker J, Steiner DF (1990) Effects of amino acid replacements within the tetrabasic cleavage site on the processing of the human insulin receptor precursor expressed in chinese hamster ovary cells. J Biol Chem 265:17230-17237.

Yoshiro K, Webster RG (1988) Sequence requirements for cleavage activation of influenza virus hemagglutinin expressed in mammalian cells. Proc Natl Acad Sci USA 85:324-328. 